\title{
Responses of east African highland banana (EAHB-AAA) cultivars to drought stress
}

\author{
S.N. Kayongo ${ }^{1,2}$, J.M. Sebuliba ${ }^{2}$ and K. Nyombi ${ }^{2}$ \\ ${ }^{1}$ Nabuin Zonal Agricultural Research and Development Institute P.O. Box 132 Moroto, Uganda \\ ${ }^{2}$ College of Agricultural and Environmental Sciences, Makerere University, P. O. Box 7062, \\ Kampala, Uganda
}

Author for correspondence: jskayongo@yahoo.com, jssebuliba@caes.mak.ac.ug

\begin{abstract}
Banana (Musa spp.) yields are estimated at 5-30 $\mathrm{tha}^{-1} \mathrm{yr}^{-1}$, lower than the potential $60 \mathrm{t} \mathrm{ha}^{-1} \mathrm{yr}^{-1}$, with the cause being drought stress. Much evidence among stakeholders shows little understanding about banana cultivar sensitivity, escape and avoidance mechanisms to drought due to un-attempted measures of retaining plant growth during escalating dry spell. This study aimed at determining cultivar expression as a way of dealing with drought. Triploid cooking cultivars of Mpologoma and Kisansa (AAA) versus the considered drought tolerant cultivars of Kayinja (ABB), Sukali ndiizi (AAB) and a low land cultivar Yangambi Km5 (AAA) were grown under a semi-micro environment, with controlled soil evapo-transpiration. Cultivars were grown on three sandy loam soil water regimes under $p F$ - curves of ${ }^{10} \log$ matrix head of Wet: 2.0-2.1 (0.1 - 0.13 bar) equivalent to $90 \%$ moisture availability (M.A.); Semi-moist: 2.5-2.7 (0.32 - 0.51 bars) equivalent to $60 \%$ M.A. and Dry: 2.8-2.9 (0.64 - 0.8 bars) for 30\% M.A., respectively. Results showed that an increase in soil moisture deficit from moist to dry condition caused a proportional loss in fresh biomass of up to $50 \%$ among cooking cultivars, and less than $40 \%$ to dessert cultivars. Leaf orientation was significant to folding with cooking variety type opening leaves widely (up to $100^{\circ}$ ), and enhancing excessive leaf plant dehydration, even during stressful conditions. Soil evapo-transpiration showed that cvs. Kisansa and Mpologoma transpired up to $1.125 \mathrm{~L} 48 \mathrm{hr}^{-1}$, exhibiting a trait for water spending than saving. Thus, cultivars comprising of genome (B) expressed crucial mechanisms of avoiding excessive effect of drought stress. Therefore, under high moisture deficits, Kayinja and Sukali ndiizi cultivars express drought avoidance mechanisms through leaf folding. But, the cooking type of cultivars Kisansa and Mpologoma (genome A), develop extensive rooting system important in search for moisture; and large leaf surface characterised by high rate of transpiration for water spending.
\end{abstract}

Key words: Musa spp., soil moisture, transpiration 


\section{Introduction}

This study therefore was conducted to quantify thresholds for banana (especially the cooking type) plant survival and avoidance mechanisms during drought stress. Five banana (triploids) cultivars from Banana program at National Agricultural Research Laboratories Institute (NARLI) were tested for response to drought stress across various soil moisture regimes. Cultivars in category of cooking banana (Mpologoma and Kisansa with genomic composition of AAA from Musa acuminate) and the dessert plantains (Kayinja: ABB; and Sukali ndiizi: $\mathrm{AB}$ hybridized from Musa balbisiana) were used in this study. Other considered cultivar included Yangambi Km5 hybridized from Musa acuminata (A) genome in the lowlands of East Africa. The choice of banana categories was based on susceptibility to drought stress (especially cooking banana), conferring hardness and tolerance to drought stress, resistance to banana diseases and containing acid-starchy fruit quality (Pillay et al., 2007) especially the dessert plantains. The categorized banana cultivars were subjected to three soil moisture regimes involving moist (free drainage level), semi-moist and drier condition for expression of drought stress avoidance mechanisms. This study was conducted under screen house microenvironment condition at International Institute of Tropical Agriculture (IITA) in Sendusu, and Makerere University. Cultivar response to drought stress involved assessing the plants potential to survive and produce at different moisture deficit levels through determining the threshold levels for biomass accumulation, leaf turgidity, root exploration, canopy orientation, senescence and chlorophyll immobilisation. The assessment aided in exploring mechanisms for variety potential to spend and or save water from excessive transpiration.

Cultivar selection depended on the importance of banana as cooking type, which consequently the most susceptible banana type to drought stress, then drought tolerance, potential for conferring hardness, tolerance to biotic stresses and ability to expression mechanisms for drought stress avoidance. The need for increasing potential for banana productivity through expression of drought avoidance /management instigated this study from reality that banana yields are low and still continuing to decline despite advances in banana breeding research. However, earlier studies by van Asten (2007) showed that banana yield increase correlates with increase with free drainage moisture and decrease with drought stress effect. Therefore generating knowledge on banana survival mechanisms (especially the dessert type) during drought stress could help understand ways to increase banana yield.

\section{Materials and methods}

\section{Study area}

The experiment was conducted in a screen house, under controlled environment at Sendusu, International Institute of Tropical Agriculture (IITA), in the field and laboratory. Sendusu site is situated at Namulonge at $0^{\circ} 53 \mathrm{~N}, 32.35 \mathrm{E}$ and at 1150 $\mathrm{m}$ above sea level. The soils of the area are classified as isohyperthermic Rhodic Kandiudalf (USDA taxonomy). They are mainly deep tropical, dark re-dish brown sandy loam, characteristic of the Buganda (Central region of Uganda) catena. Soils are heavy, well drained with a $\mathrm{pH}$ range 
of 5-6, and average organic matter levels of $2-3 \%$ in the surface horizons.

The climate of the area is tropical, with minimum and maximum temperatures of 15 and $31^{\circ} \mathrm{C}$, respectively. The station experiences bimodal rainfall distribution of about $968.8 \mathrm{~mm}$ annually, with the main rains occurring from March to June (127.3 $\mathrm{mm}$ ), while short rains fall between September and December $(78.3 \mathrm{~mm})$.

\section{Experimental layout}

The experiment was laid out in a completely randomised design with three replications. Treatments included moisture regime, variety and sampling time. Three levels involving three moisture regimes viz free drainage, the semi-moist and the drier condition. Five banana varieties, cv. Mporogoma and Kisansa (AAA) that are considered prone to drought stress (Bananuka, 1999) were control cultivars; cv. Yangambi km5 (AAA) a low-land adapted triploid cultivar, were considered tolerant to drought stress possibly due to its water use efficiency and its responsive ereclophile morphological that enhance maximum solar radiation interception; cv. Sukali ndiizi (AAB) and cv. Kayinja $(\mathrm{ABB})$ that are considered tolerant to drought stress. Different data parameters were collected at different times to enhance the assessment of the plant performance at various growth stages.

\section{Materials used}

Materials used in the study included tissue cultured banana seedlings; steam sterilised soils free from soil microbes; perforated 30L buckets; polythene plastic for covering the bucket to control at least $95 \%$ soil evapo-transpiration; fertilisers (Muriate of potash) applied to ensure no nutrition deficiency across treatments; a steady-state porometer machine for collection of stomata conductance data; chlorophyll meter to measure the nutritive aspect of the plants; a protractor and compass for assessing the canopy structural behaviour (angle and folding) of the leaves.

\section{Treatments imposition}

Five tissue cultured seedlings (three months old) were planted each in a $30 \mathrm{~L}$ bucket and subjected to three moisture regimes. Moisture treatments were quantified based on the $p F$ curves of ${ }^{10} \log$ matrix head of soil water $(-h \mathrm{~m} / \mathrm{cm})$. The three levels of moisture regime were imposed as follows: ( $\mathrm{MD}_{1}$ - moist soils) $p F$ (soil water retention potential) 2.0-2.1 (moist; 0.1 - 0.13 bars) equivalent to field capacity of $90 \%$ M.A. (10\% moisture deficit); ( $\mathrm{MD}_{2}=$ semi moist soils $) p F 2.5$ 2.7 (semi-moist; 0.4 - 0.51 bars) equivalent to soil moisture availability of $60 \%(40 \%$ moisture deficit); and ( $\mathrm{MD}_{3}$ - dry soils) $p F$ 2.8-2.9 (dry; 0.74 - 0.8 bars) equivalent to soil moisture availability of $30 \%(70 \%$ moisture deficit) $(1 \mathrm{bar}=0.986923 \mathrm{~atm}=$ $100 \mathrm{kPa}=1.02 \mathrm{~kg} \mathrm{~cm}^{-2}$.

The pressure extractions in bars for best results were setup at an average of 0.15 bars equivalent of $\log _{1.0}\left(10^{2}\right)-\log _{1.5}$ $\left(10^{2}\right)$ for $p F$ 2.0-2.1; then 0.45 bars equivalent of $\left(\log _{3.5}\left(10^{2}\right)-\log _{5}\left(10^{2}\right)\right.$ for $p F 2.5-2.7)$; and 0.8 bars equivalent of $\left(\log _{7}\left(10^{2}\right)-\log _{8.5}\left(10^{2}\right)\right.$ for $p F$ 2.8-2.9) through using ceramic plates. However, the ideal curve for $p F$ (moisture retention potential) was obtained from literature by Kumar and Mittal (2010).

The $p F$-ranges for soil moisture regimes were maintained and monitored with pressure (in centibars) gauged tensiometers placed around the root zone of the selected potted plants per treatment structure to measure soil volumetric potential by gauging the soil water 
equilibrium with the extraction pressure through a permeable cup in contact with the soil. Upon drying of the soil, water potential decreases and the pressure increases in the tensiometer vacuum. Conversely, the increase in soil water content through water addition for maintaining the $p F$ ranges, decreases tension and lowers the vacuum gauge reading. Water volumes of $0.8,0.6$ and $0.4 \mathrm{~L}$ for minimum and maximum $p F$ ranges of each treatment regime, were applied to plants after every 48 hours, to replace water lost through leaf transpiration. A weight model for the soil mass, water and the cumulative plant weight were also developed to enhance calibration of moisture treatment adjustments for maintenance within the required moisture ranges. The model variables included:

(a) Cumulative weight of plant, involving cumulative increase in volume of the plant and biomass growth.

(b) Soil water model, $\quad \mathrm{WSp}_{\mathrm{i}-\mathrm{j}}=\left(\mathrm{W}_{\mathrm{b}}+\right.$ $\mathrm{V}_{\mathrm{H} 20}$ ), Whereby: $\mathrm{WSp}_{\mathrm{i}-\mathrm{j}}=$ Weight of soil at corresponding soil $p F$ ranges:

(i) $p F$ range $(2.0-2.1 ; 2.5-2.7 ; 2.8-2.9)$ based on $p F$ curve sandy loam suction pressure;

(ii) Weight of soil at $p F$ level $=$ weight of soil $* 2.65 *\left(1-_{\text {pore volume fraction }}\right)+$ pore volume fraction * weight of soil * relative saturation (ie weight soil at eg pF $2=76.85-76.85 *$ pore volume fraction $+17.748 *$ pore volume fraction; pore volume fraction = (weight soil at $p F 2-76.85) /(-76.85$ $+17.748)$ ); $\mathrm{W}_{\mathrm{b}}=$ Weight of empty bucket; $\mathrm{V}_{\mathrm{H} 20}=$ Volume of water at indicated $p F$ level. Soil volume* Pore volume fraction* relative saturation (ie fraction of pores filled with water at the indicated $p F$ level)

\section{Weight loss allometric nonlinear model}

Calibration for weight loss depended on the developed logistic nonlinear model, involving discrete variables of plant biomass accumulation weight and soil mass at corresponding $p F$ ranges, to predict the final weight for plant growth structures at free drainage as follows:

$Y=\left(\left(T F W=(B A W)+\left(A=\pi r^{2} h\right)\right)+\right.$ $\left.\left(W S p_{i-j}=S M V^{*} P V F^{*} R S\right)+W b+V W A\right)$. $\mathrm{Y}=3.5317 \mathrm{x}-695.26 ; \mathrm{R}^{2}=0.9889$

$\mathrm{Y}=$ Final weight of plant, TFW = Total fresh weight of plant, BAW= Biomass Accumulation Weight, $\mathrm{A}=$ Volume of plant based on $\mathrm{a}=\mathrm{mx}-\mathrm{b}$, where predicted $A$ is based on slope of observed biomass less the intercept value on vertical axis. $\mathrm{WSp}_{\mathrm{i}-\mathrm{j}}=$ Weight of soil at corresponding soil $p F$ ranges, $\mathrm{W}_{\mathrm{b}}=$ Weight of empty bucket, $\mathrm{V}_{\mathrm{H} 20}=$ Volume of water at indicated $p F$ level, SMV = Soil mass volume, $\mathrm{PVF}=$ Pore volume fraction, $\mathrm{RS}$ $=$ Relative saturation and VWA $=$ Volume of water Added.

The biomass accumulative weight was based on below ground (roots and corm) and above ground (stem, leaf number, leaf weight and area); and plant volume $\left(\pi r^{2} h\right.$ of the stem). Leaf area was based on length and width of the third most fully developed leaf (Turner, 2005) from the top of plant.

One plant per variety and treatment were destructively harvested every month to determine the corresponding weight of root and corm as a unit structure for the remaining plants in the experiment. Stem weight was based on plant height and girth (average top and bottom girth). The total weight of potted plants (plant, pot, water 
and soil) at corresponding soil $p F$ ranges was determined as follows:

Total weight of potted plant $=(p F R *$ pFM*RS* Wbfd*Web* Wplt *WspFL* $\left.S V^{*} P V F^{*} B / d^{*} D M S * W b^{*} S w\right)$

The quantified $p F$ ranges for minimum and maximum levels for water addition to the bucket for the three moisture regimes (Moist, semi-moist and dry) was determined.

\section{Data collection}

\section{Plant biomass}

The responsive biomass accumulation was assessed fortnightly, beginning at $1 \mathrm{MAP}$, by taking measurements of plant height $(\mathrm{cm})$, girth $(\mathrm{cm})$, size of leaf lamina (Leaf length and width) and the number of productive tillers. All measurements on leaves were taken on the third leaf (Kumar, 2002) from the top due to its full expansion. Leaf area was calculated from the taken leaf lamina size by the constant factor of 0.688. Biomass accumulation parameters were assessed after every two weeks, to enhance the determination of the cumulative weight increase of the plant for collective maintenance of soil $p F$ range treatments based on the plant absorption rate of moisture. Root growth and distribution were determined using morphological parameters of root girth size and specific root length (SRL, $\mathrm{m} \mathrm{g}^{-1}$ ) Ostonen et al. (2007) as an indicator of soil environmental change in determining the length of fine roots. At the thirteenth week of plants growth, the experiment was terminated and all plants were harvested to assess the dry mater of the responsive and below ground biomass (roots).
Canopy structural architecture

\section{Leaf angle architectural behaviour}

Canopy leaf orientation is an important parameter for plant growth modeling. The behavioural component of the leaves in terms of leaf angle and folding, are a mechanism for combating the adverse effects of drought stress especially heat and moisture deficit. Leaf lamina is liable to change the standing angle and also fold to avoid excessive transpiration.

The leaf angle behavioral data (degrees) were collected on weekly basis using a geometry protractor for an exponential vertical-horizontal relationship between the mid leaf and the third most fully expanded leaf. Due to the stress and environmental effects induced in leaf angles (Tosserams et al., 1997), determination of canopy architecture is important in characterisation of susceptible cultivars. Consequently, average canopy leaf angle is used as a functional parameter in most photosynthetic models (Aries et al., 1993; Thornley and Johnson, 1993).

\section{Leaf folding behaviour}

A drastic decrease in soil water content, from the field capacity, can cause a stress situation of plant dehydration due to lack total soil available moisture (TAM) for plant growth. Leaf biomass is mostly deterred from expansion due to reduced leaf water potential (LWP), yet transpiration rate is high. By avoiding a dehydration phenomenon of excessive loss of leaf water, banana plants develop a mechanism of reducing the leaf evaporative surface area through folding the midrib of upper leaves (Kusaka, 2005). This mechanism improves the plant water use efficiency, and maintains a relatively 
positive leaf water potential and efficient stomata regulation of transpiration (Shmueli, 1953). Thus, data were collected on a weekly basis, to assess the degrees to which leaves of different banana cultivars exhibited the folding mechanism for enhancing control of excessive transpiration. A geometry compass was used at the middle of the third most developed leaf lamina and determined the folding by reading corresponding degrees on a protractor.

\section{Leaf water content}

The relative leaf water content is a relevant physiological component for assessing the leaf osmotic potential. It is a variable for estimation of current water content of the leaf tissue, relative to the maximal water content it can hold at full turgidity, in a situation of moisture deficits. At subsequent destructive harvestings, a direct approach for assessment of leaf water content was adopted in the analysis, whereby a third fully expanded leaf from the plant apex was selected and cut out five leaf discs (diameter $0.5 \mathrm{~cm}$ ) from the middle region.

The leaf discs were put in a vial after determining their fresh weight, and then rehydrated with $5 \mathrm{ml}$ of distilled water and refrigerated at $4{ }^{\circ} \mathrm{C}$ for 48 hours. The leaf discs were then blotted with a dry piece of cloth, weighed and dried in the oven at $70{ }^{\circ} \mathrm{C}$ for 72 hours. The success in determining the sensitivity of banana cultivars to dehydration was based on the following formula:

$\operatorname{RWC}(\%)=[(F W-D W) /(T W-D W)] x$ 100 (Rampino, 2006) and Water loss rate (WLR) (Suprunova et al., 2004)

Where FW = Fresh weight, TW or SW= turgidity or saturation weight and DW= dry weight. Therefore, the maintenance of a positive turgor under water stress is an indication of osmotic adjustment which is drought avoiding mechanism.

\section{Transpiration process}

Transpiration and stomatal conductance are processes that appear to depend directly on leaf water potential, which in turn depends on the balance between evaporative demand and the ability of the plant to extract soil moisture (Azam-Ali, 1983). Transpiration is, therefore, a reliable indicator of stress initiation in the banana plants, although indirectly related to soil water deficits.

The sensitivity of banana plants to levels of soil moisture depletion justified the need for characterisation of physiological parameters, especially transpiration rate to water stress in identifying the initiation of stress, and in planning drought management accordingly. In obtaining the data, a weight loss method was adopted where potted buckets were covered with a plastic polythene sheet to atleast control 95 percent of soil evapo-transpiration and only allow loss of water through leaves transpiration. Treatments were maintained at determined $p F$ levels corresponding to weight ranges of the soil mass, and the plant biomass. Volumes of transpired water were assessed after every 48 hours through weight loss in soil water model.

\section{Chlorophyll response}

Chlorophyll breakdown assessment is a valuable index method for evaluation of plant tolerance to drought stress (Paknejad et al., 2007). Drought stress affects photosynthetic process and also causes the malfunction of biochemical reactions (Lauer and Boyer, 1992). The photosystem11 (PS11) is highly sensitive 
to environmental limiting factors and its chemical reaction being adversely affected by drought stress (Cornic, 1994; Vazan, 2002). Therefore, data were taken from a noninvasive chlorophyll meter (SPAD; Minolta, Osaka, Japan) attached on the third unfolding banana leaf to determine the rate of $\mathrm{N}_{2}$ accumulation in leaves at varying moisture deficits and data collected at a monthly basis starting from the time when treatments were imposed to harvesting. A chlorophyll meter reading correlates well with analytical measurements of the chlorophyll content and with $\mathrm{N}$ concentrations in the leaves (Vos and Bom, 1993).

\section{Results and discussion}

\section{Below ground biomass}

Reduction in moisture availability (M.A.) from $p F 2.0$ to 2.5 showed a proportional reduction in fresh root biomass of 35.3\% for cv Sukali ndiizi, more than other cultivars whose fresh weight loss ranged from 12.7 - 19.4\% (Table 1). Further reduction of moisture availability from $p F$ 2.5 to 2.8 significantly affected the cooking cv. Mpologoma by $54.4 \%$ loss in fresh root weight, cv. Kisansa $46.5 \%$, Sukali ndiizi $43.0 \%$, Kayinja $42.0 \%$ and Yangambi Km5 with 40.0\% (Table 1). Overall results, therefore, showed that in regards to root sensitivity to drought, highland banana cultivars conforming to triple AAA genome composition were more sensitive to moisture stress reduction than cultivars belonging to $\mathrm{AAB}$ and $\mathrm{ABB}$ genomes. However, lowland cultivar, Yangambi Km5, was least affected by moisture reduction. This suggested the possibility of possessing expressive traits adaptable to drought. In earlier studies by Sebuwufu et al. (2004), 90\% of the variations in root growth were attributed to variation in shoot development which is similarly affected by moisture deficit. Similarly, Blomme (1996) also reported positive correlations between root traits and above ground plant characteristics. Therefore, with the reduction in fresh weights, suggestions of resulting effects were attributed to affected plant shoot due to moisture deficit.

\section{Root characteristics}

Most root sizes were less than $1 \mathrm{~cm}$ in diameter, with girth size not significantly different across cultivars, but by moisture regimes. The small root size and girth indicated the presence of more lateral roots and therefore led to suggestion that more root length occurred in small roots with diameter $<1 \mathrm{~cm}$ (Fig. 1). Significant average root lengths across moisture deficit levels were observed for $p F 2.0$, 2.5 with cv. Mpologoma at 38.4, 49.4, $29.4 \mathrm{~cm}$, and cv Sukali ndiizi at 53.3, 45.9 and $32.7 \mathrm{~cm}$, respectively across moisture deficit regimes (Table 1). Cooking type of cultivars attained the maximum root lengths (MRL), with Kisansa (AAA) exhibiting $118,114.4$ and $80.9 \mathrm{~cm}$ at $p F$ $2.0,2.5$ and 2.8 , respectively. The cultivar also attained a root tissue density of 161 , 74 and 69 corresponding to $p F 2.0,2.5$ and 2.8, respectively; whilst, cv. Mpologoma had 96.9, 109.2 and $84.3 \mathrm{~cm}$ and root tissue density of 130, 100 and 71 for the respective moisture levels $(p F 2.0$, 2.5 and 2.8) (Table 1).

The observation suggests that higher proportion of tissue density and length potentially develops in a more moisture stressful condition, partly due to development in search for moisture. Cultivar Kayinja $(77.4,91.8$ and $73.3 \mathrm{~cm})$ and Yangambi Km5 (76.9, 81.8 and 83.2 $\mathrm{cm})$ exhibited the most limited length of root and were not significantly different 


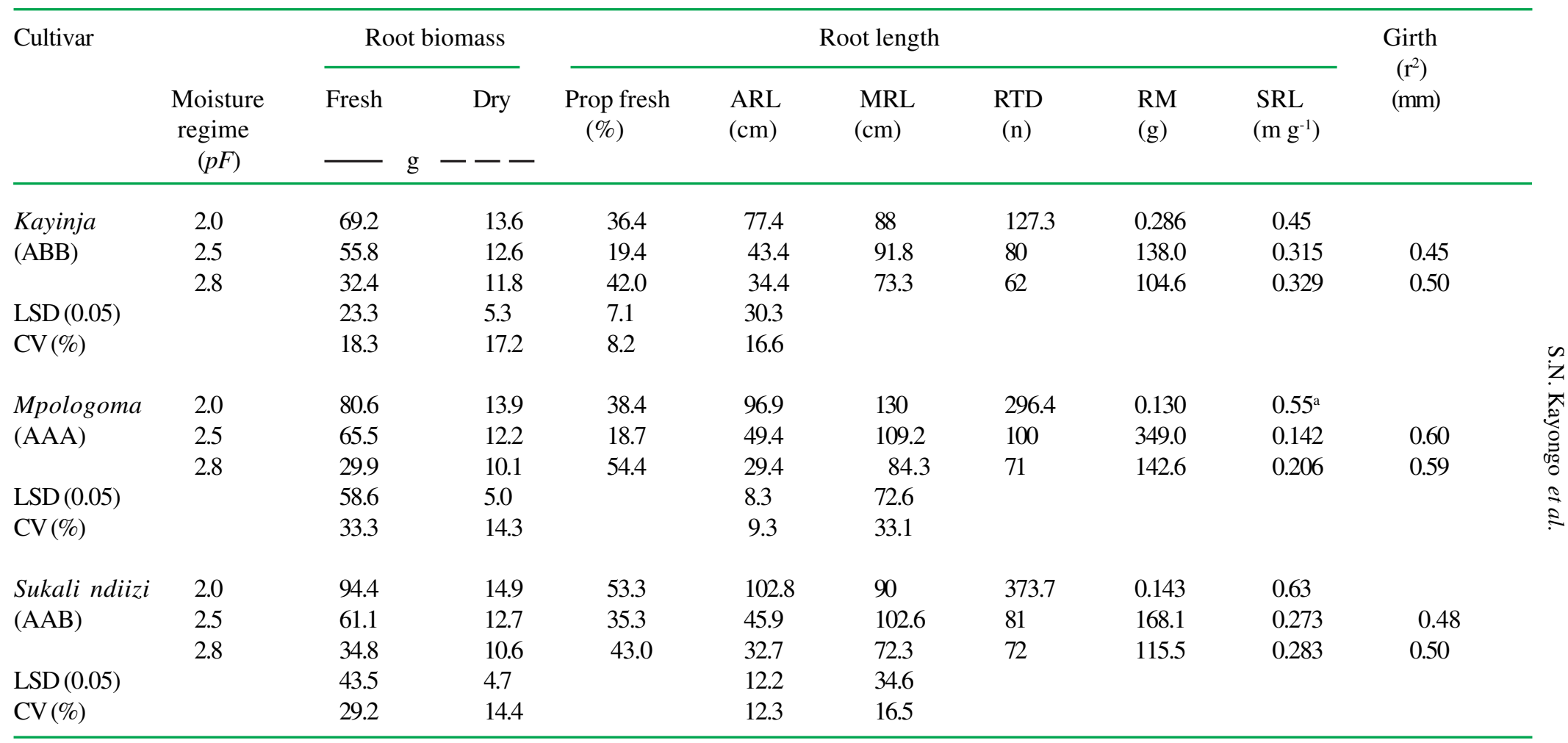


Table 1. Condt.

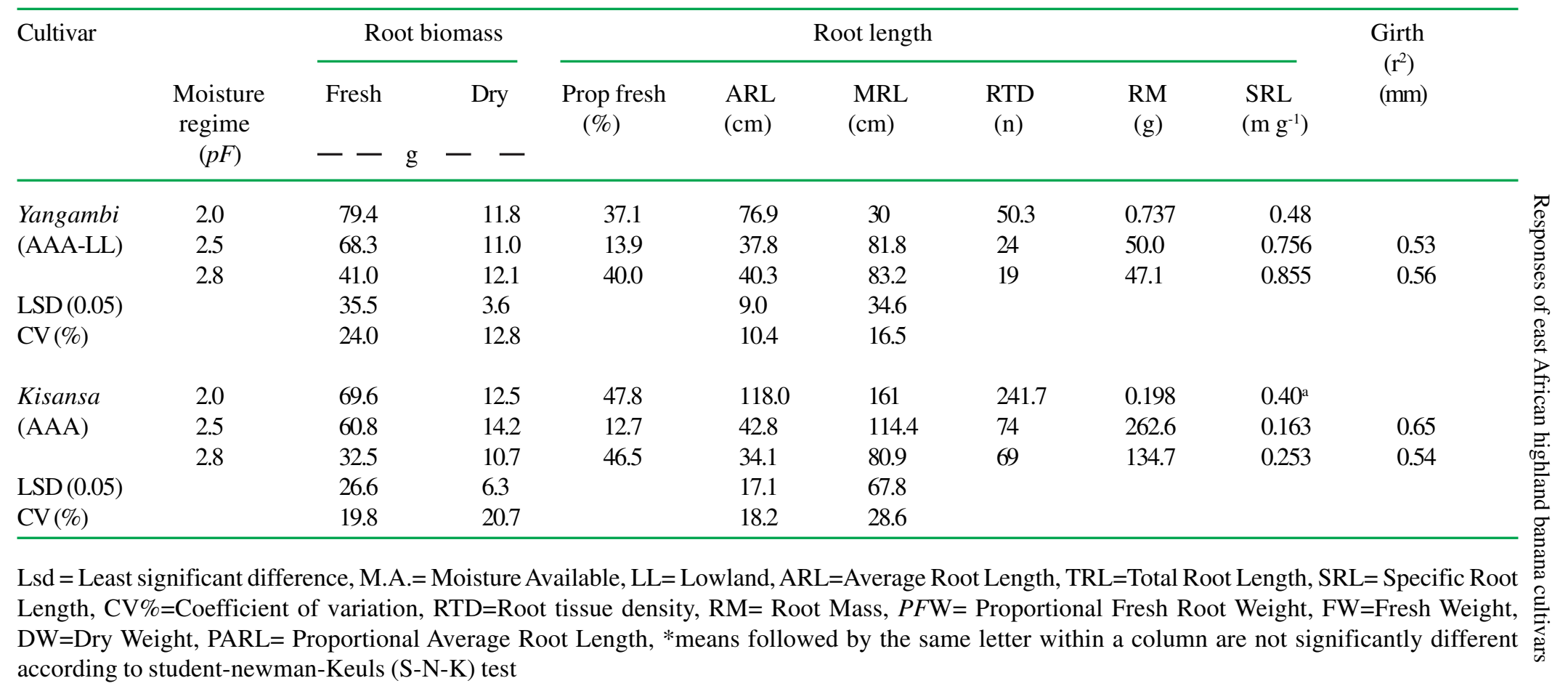




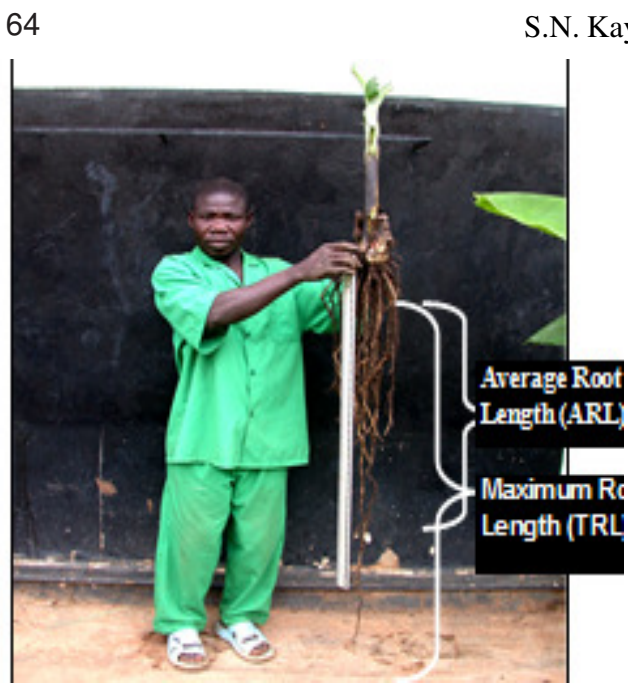

Figure 1. Banana root length at harvest

across moisture deficit levels. Cultivar Yangambi Km5 had the lowest density of roots at 30,24, and 19 for the $p F 2.0,2.5$ and 2.8 , respectively.

The low root tissue density was attributed to the narrow shoot nature of cv. Yangambi Km5 from the compensation point, than to the effect of moisture deficit. The proportional change in average root length (ARL) (Fig. 1), as a result of increased moisture deficit, showed a tremendous effect of drought stress. Cultivar Mpologoma exhibited more root mass 296.4, 349.0 and $142.6 \mathrm{~g}$ and cv. Kisansa with 241.7, 262.6 and $134.7 \mathrm{~g}$ for the $p F 2.0,2.5$ and 2.8, respectively. Cultivar Sukali ndiizi equally exhibited high root mass $(373.7,168.1$ and $115.5 \mathrm{~g}$ ) for $p F 2.0,2.5$ and 2.8 , respectively. The exhibition of high root mass among the cooking type of cultivars is an indication of efficient shoot/root ratio.

High root mass, therefore, puts the cooking type of cultivars to being sensitive to drought stress during moisture deficit. Cultivars Kayinja and Yangambi Km5 exhibited lower root mass (127.3, 138.0, 104.6; and 50.3, 50.0 and $47.1 \mathrm{~g}$ for the $p F$ 2.0, 2.5 and 2.8, respectively. The possession of low root mass was suggested to be a drought adaptive mechanism to the plant since relatively little volume of water may be absorbed for plant growth.

\section{Specific root length}

The lowest Specific root length (SRL) $\left(\mathrm{SRL}=L / M=L / R T D^{*} V=L / R T D\right.$ $(\pi D 2 / 4) * L$ where $L / M=$ length -to mass ration; $\mathrm{RTD}=$ root tissue density; $\mathrm{D}=$ root diameter) were exhibited by cv Mpologoma $\left(0.130 \mathrm{~m} \mathrm{~g}^{-1}\right)$, cv. Kisansa $\left(0.198 \mathrm{mg}^{-1}\right)$ and cv. Sukali ndiizi $(0.143$ $\mathrm{mg}^{-1}$ ) (Table 1) at $p F 2.5$ correlating with a larger leaf surface area. However, cultivars Kayinja and Yangambi Km5 scored significantly higher SRL ( 0.3 and $0.7 \mathrm{mg}^{-1}$, respectively), hence proving the increase of SRL to decreasing leaf area (Figs. 1 and 2). Progressively, increased SRL with increased moisture deficit coincided with reduced leaf surface hence a low shoot/root ratio.

With similar phenomena, Eissenstat and Yanai (1997) assumed root length and root mass (RM) to be proportional to resource acquisition and plant maintenance, respectively. High SRL, with decreased moisture deficit concurred with Withington et al. (2006) observation that long and thin roots (high SRL) were the below ground equivalent of thin leaves and leaf area could be estimated from cord roots (Gousseland, 1983), and changes in the rate of shoot growth result on an effect in root growth (Blomme et al., 2008). Although cv. Mpologoma, and cv. Kisansa attained a higher root length (Table 1), their proportion of root length and density reduction due to moisture deficit indicated that they were most susceptible to moisture deficit. But their potential for a large leaf area proved a relationship for efficient utilisation of 
Variety spedific root threshold level

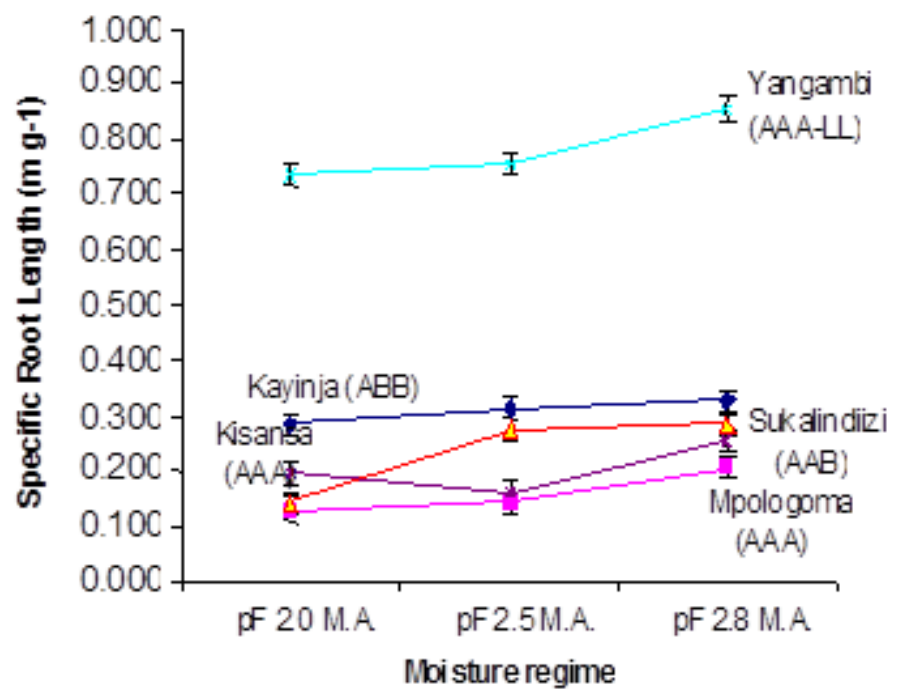

Figure 2. Root length of selected banana cultivars across moisture deficit regimes.

available moisture but not water saving due to limited root distribution across continued moisture deficit levels.

At $p F 2.5$, values of 0.142 and 0.163 $\mathrm{mg}^{-1}$ were observed as levels for the specific root length development of $\mathrm{cv}$. Mpologoma and Kisansa, respectively (Fig. 2). Further increment in moisture deficit level to $p F 2.8$ would increase the SRL value with limited root mass, while increases in the available soil moisture to $p F 2.0$ increase the root tissue density. However, cv. Sukali ndiizi developed high root tissue density (RD) due increased availability soil moisture $(p F 2.0)$ than the lowered moisture levels, suggesting $<p F$ 2.5 as the threshold level at a value of $0.273 \mathrm{~m} \mathrm{~g}^{-1}$ (Table 1 and Fig. 1). The validity of the observation could be proved with the narrow leaf length and low shoot/ root ratio.

\section{Relative root dry weight}

The mean root dry weight was expressed as relative percentage to the fresh weight. The relative dry matter of root was generally higher among plants at $p F 2.8$ M.A. (stressed cultivars) than plant growth at free drainage level (Table 1). Cultivar Kayinja exhibited the highest dry root weight (36.5\%), followed by cv. Mpologoma (33.7\%), cv. Sukali ndiizi (30.3\%) and cv. Kisansa (33.0\%) and cv. Yangambi Km5 (29.5\%) for the $p F 2.8$. This suggests potential for substrates concentration in moisture stressed than non stressed roots, which could be driven by increase in temperature and probably the pressure in the root zone. The threshold levels for both fresh and dry biomass matter were observed at $p F 2.5$ based on the relative slope of the curves for all cultivars.

The hierarchal order of hydration within the stressed plants ( $p F$ 2.8M.A.) were indicated among cv. Kayinja $\left(1.74 \mathrm{~g} \mathrm{H}_{2} \mathrm{O} /\right.$ DM g $\left.{ }^{-1}\right)$, cv. Mpologoma (1.97 g H$_{2} 0 /$ $\mathrm{DM} \mathrm{g}^{-1)}$, cv. Kisansa (2.03 g $\mathrm{H}_{2} 0 / \mathrm{DM}$ $\left.\mathrm{g}^{-1}\right)$, and Sukali ndiizi $\left(2.30 \mathrm{~g} \mathrm{H}_{2} \mathrm{O} / \mathrm{DM}\right.$ $\left.\mathrm{g}^{-1}\right)$ and cv. Yangambi Km5 (2.38 $\mathrm{g} \mathrm{H}_{2} \mathrm{O} /$ $\left.\mathrm{DM} \mathrm{g}^{-1}\right)$. The order indicated that cultivar Yangambi Km5, Sukali ndiizi and 
Kisansa used relatively more water to produce a single unit of dry matter, suggesting the potential for root desiccation during drought period.

\section{Above ground biomass}

Plant height (1MAT imposition). At field capacity ( $p F 2.0 \mathrm{MA}$ level), plants attained the highest plant height (67 - 86 and $64-93 \mathrm{~cm}$ ), respectively. However, increase in height slowed gradually at 60 $-83 \mathrm{~cm}$ high ( $p F 2.5$ M.A) and $46-64 \mathrm{~cm}$ ( $p F 2.8$ M.A.), especially during $2008 \mathrm{~b}$ season. The difference in height across moisture deficit levels, exhibited a clear indication of the impact of moisture stress on the plant's potential to grow tall. Cultivars, Mpologoma, Kisansa, Kayinja and Yangambi Km5 were relatively short species $(67-76 \mathrm{~cm}$ and $64-82 \mathrm{~cm}$ for $2008 \mathrm{~A}$ and B seasons) even at field capacity level (Fig. 3). The observed significant reductions in plant height were attributed to decreased available moisture that caused retarded plant growth.

\section{Stem girth development}

Average threshold girth sizes were 12.6 $\mathrm{cm}$ (Yangambi Km5), $13.5 \mathrm{~cm}$ (Mpologoma) and $14.0 \mathrm{~cm}$ for Kisansa. However, a significant limitation of stem development was observed with continuous increase in moisture stress. At harvest, with $p F$ 2.5., cv. Sukali ndiizi $(19.3 ; 24.0 \mathrm{~cm})$ and cv. Kayinja (18.8; $18.6 \mathrm{~cm}) \mathrm{cv}$. Mpologoma $(16.5 ; 16.8 \mathrm{~cm})$ exhibited the largest stem circumference than cv. Yangambi Km5 $(15.5 ; 13.9 \mathrm{~cm})$ and cv. Kisansa $(15.2 ; 16.4 \mathrm{~cm})$ (Fig. 4) for $2008 \mathrm{~A}$ and B seasons, respectively. However, at $p F 2.5$, the stem enlargement potential of cv. Kayinja, Sukali ndiizi and cv. Kisansa tolerated the reduction in available moisture much more than $\mathrm{cv}$. Yangambi Km5, cv. Mpologoma. With

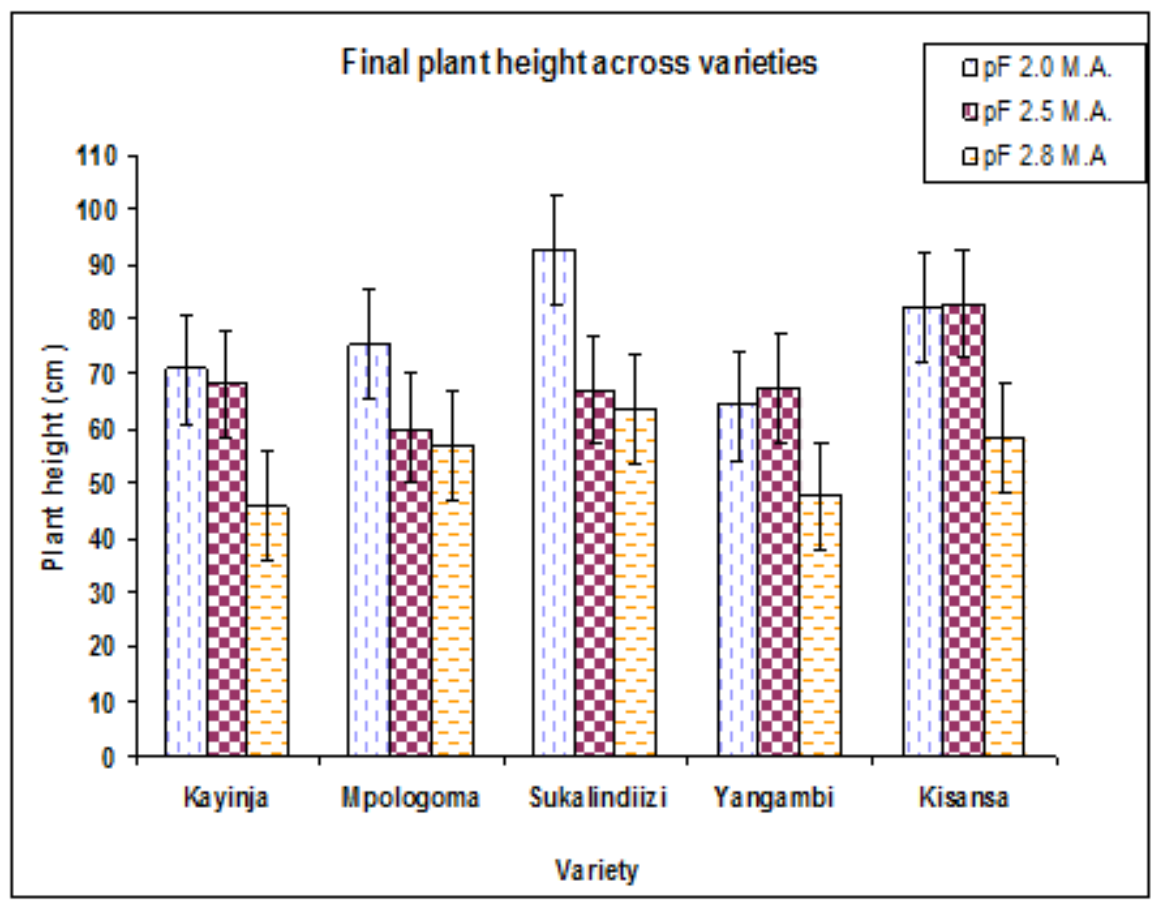

Figure 3. Mean plant height of cultivars across various moisture regimes. 
the increased moisture deficit of severe stress environment ( $p F$ 2.8), cv. Kisansa $(10.2 ; 11.0 \mathrm{~cm})$, cv. Yangambi Km5 (10.6, $11.0 \mathrm{~cm})$ and cv. Mpologoma (10.5; 12.2 $\mathrm{cm})$ were highly stressed than cv. Kayinja $(12.6 \mathrm{~cm} ; 12.5 \mathrm{~cm})$ and cv. Sukali ndiizi (12.2; $12.5 \mathrm{~cm}$ ) (Fig. 4) for 2008 A and B seasons, respectively.

\section{Cultivar leaf area expansion}

Leaf area expanded in size with maximum water availability ( $p F 2$ 2.0.) and diminished subsequently upon reduction in soil available water (Fig. 6). Similar effects were observed by Alves (2004) on limited leaf area expansion of cassava due to water deficit. However at field capacity (free drainage), cv. Sukali ndiizi (0.275; $\left.0.271 \mathrm{~cm}^{2}\right)$, and Kisansa (0.519; 0.209 $\mathrm{cm}^{2}$ ) produced the largest leaf area than cv. Kayinja $\left(0.191 ; 0.181 \mathrm{~cm}^{2}\right)$, Mpologoma $\left(0.171 ; 0.189 \mathrm{~cm}^{2}\right)$ and $\mathrm{cv}$.
Yangambi Km5 $\left(0.092 \mathrm{~cm}^{2}\right)$ for $2008 \mathrm{~A}$ and B seasons, respectively. The increase in moisture deficit from $p F 2.0-2.5$ affected the plant's potential for leaf area expansion by $30.7 \%$ (Kayinja), $31 \%$ (Sukali ndiizi) and pF 2.8 (Mpologoma) (Fig. 5).

The scores led to a suggestion that for proper leaf expansion in size, moisture should be maintained at field capacity level, hence, the threshold controlled at $p F 2.0$. Upon reducing the available moisture from $p F 2.0$ to 2.5 , the leaf area of cv. Kayinja gradually diminished immediately from $0.162 \mathrm{~cm}^{2}$, correlating with the $18.3 \%$ proportion of leaf size reduction. Cultivar Kisansa and Yangambi Km5 possessed a similar mode of significant deviated in leaf size reduction when the available moisture was decreased from $p F 2.5$ to 2.8 , hence indicating a threshold value of 0.099 and $0.090 \mathrm{~cm}^{2}$, respectively.

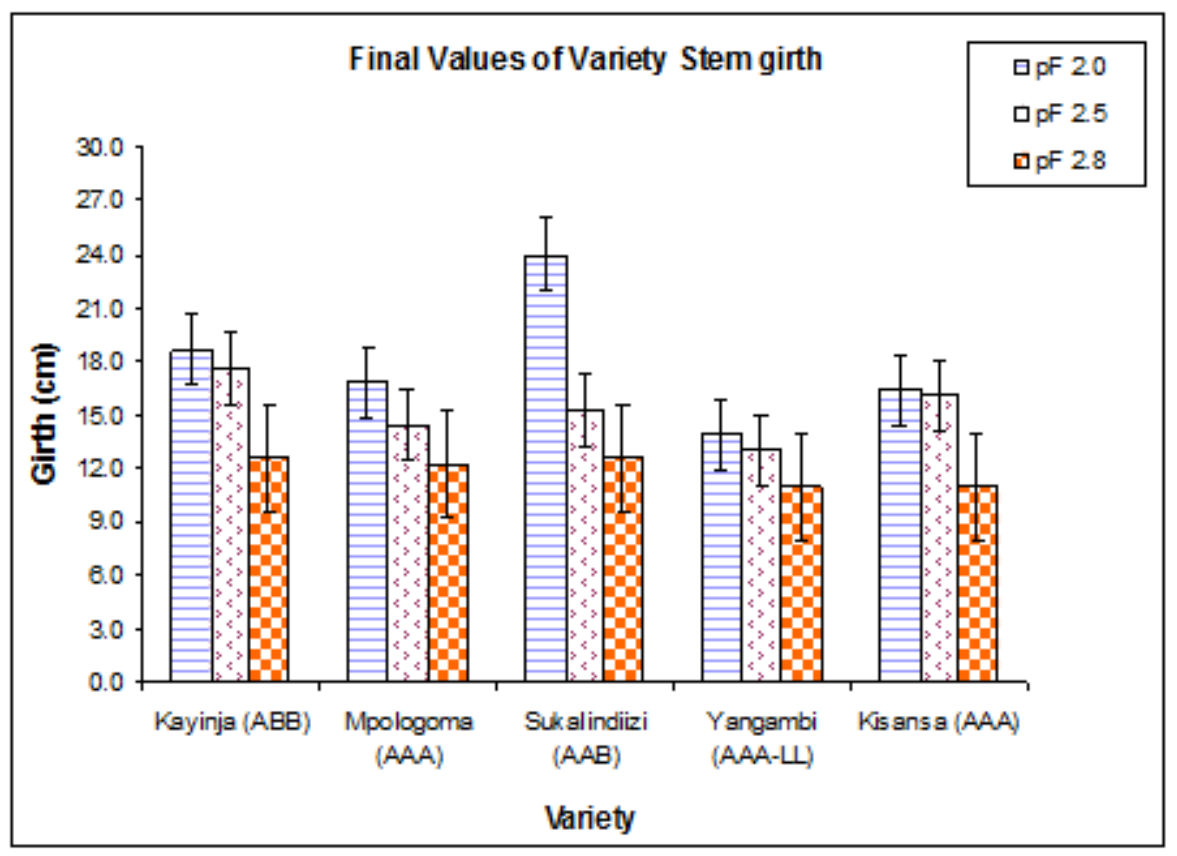

Figure 4. Cultivar stem girth across moisture regimes. 


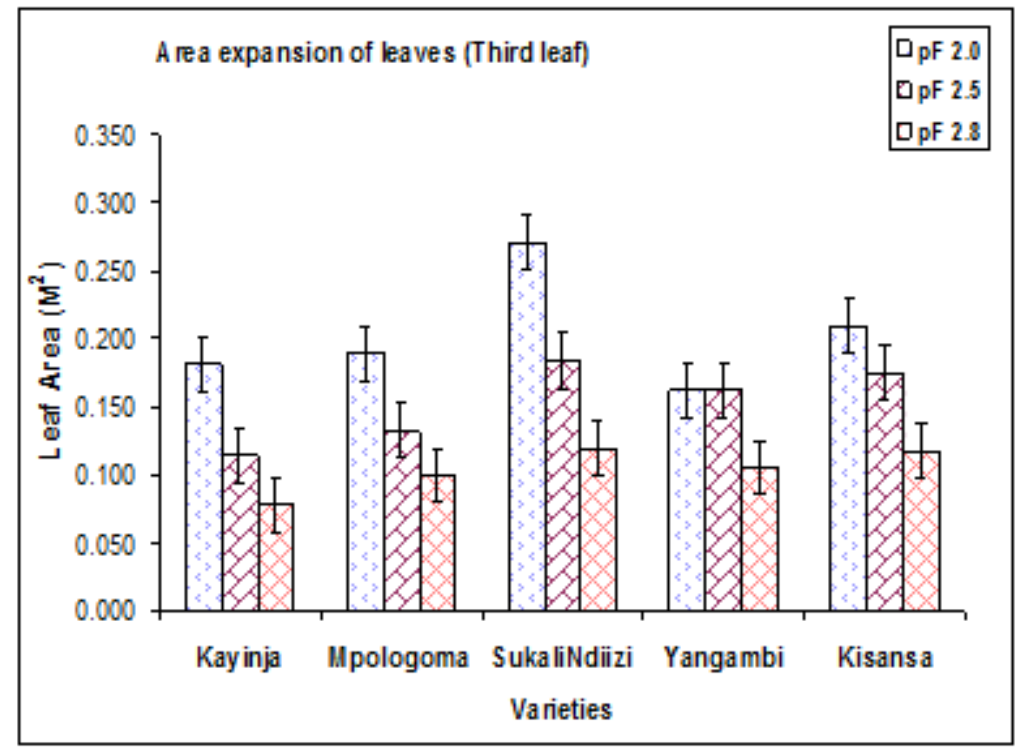

Figure 5. Leaf expansion potential of selected banana cultivars.

Fresh biomass development and
quantification The quantification of fresh biomass (leaf, stem, corm and roots) was conducted cumulatively with destructive sampling for four plant growth months beginning at one month after sucker establishment (1MASE). At harvest (4MASE), cv. Sukali ndiizi (AAB) developed the highest average fresh biomass $(2980,1264$ and $819 \mathrm{~g}$ for $p F 2.0,2.5$ and 2.8, respectively) (Table 2), (Fig. 6), indicating a cumulative proportion decrease of 58.0 and $48.0 \%$ in weight upon available moisture reduction from $p F 2.0$ to 2.5 and 2.5 to 2.8 levels.

The cooking cultivars (Kisansa and Mpologoma) developed well with 2217.5, 1050.5 and $685 \mathrm{~g}$ (cv. Mpologoma) and $2278.5,1265.5$ and $654.5 \mathrm{~g}$ (cv. Kisansa) for $p F 2.0,2.5$ and 2.8, respectively. This indicated a cumulative proportion decrease, reduction from $p F 2.0$ to 2.5 ; with $69 \%$ and $52 \%$ from $p F 2.5$ to 2.8 levels, respectively (Fig. 6). Subsequently, cv. Kayinja (ABB) finally weighed $2358.5,1113$ and $659.5 \mathrm{~g}$ for $p F 2.0,2.5$ and 2.8 levels (Table 2) with cumulative proportion decrease of 31 and $68 \%$ for moisture reduction from $p F 2.0$ to 2.5 and 2.5 to 2.8 levels, respectively. The results showed cv. Kayinja susceptibility to fresh biomass loss when moisture deficit levels decreased from $p F 2.5$ to 2.8 . The threshold critical points for cultivar susceptibility to drought stress were first determined through comparison of cooking banana cultivars (Mpologoma and Kisansa) with genomic composition of AAA together with the dessert cultivar of AAB (Sukali ndiizi).

Biomass loss was observed when moisture deficit levels were increased from $p F 2.0$ to 2.5 (Table 2). However, in comparison of cooking banana cultivars and cv. Kayinja (ABB), the lowest fresh biomass was produced with cv. Kayinja at $p F 2.0$ with a less gradual decrease in weight than the cooking cultivars of Mpologoma and cv. Kisansa (Fig. 6). 
Table 2. Monthly accumulated fresh weight growth (leaf, stem, corm and roots) of selected banana cultivars across different moisture regime

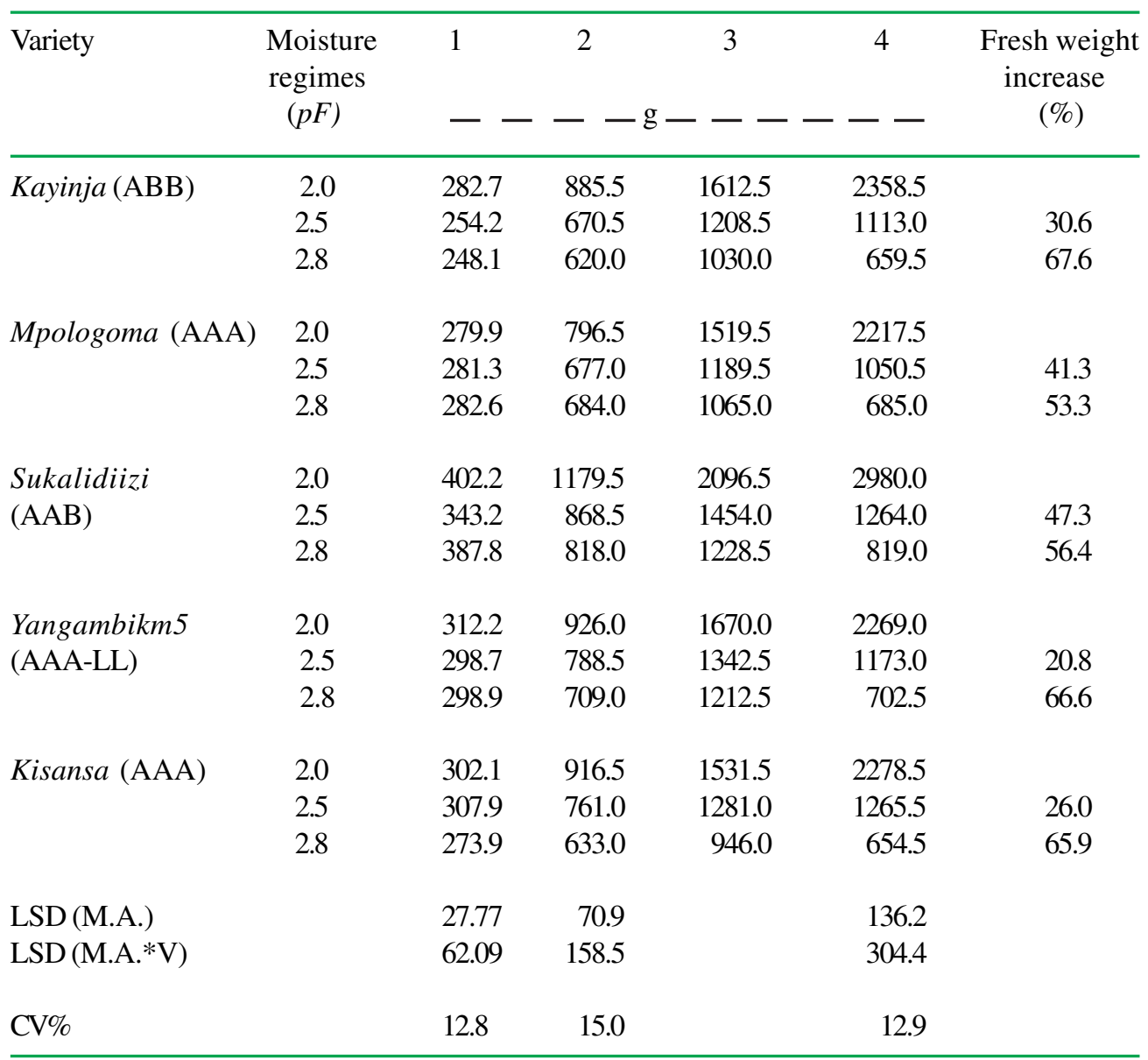

$\mathrm{MA}=$ MoistureAvailable, $\mathrm{PL}$ wgt $=$ proportional loss in biomass

\section{Banana crop survival mechanisms}

Leaf angle architectural behaviour

Banana leaves expressed the mechanism of drought avoidance most likely by changing the inclination angle through drooping or standing state based on diurnal period differences. Across seasons, cv. Kisansa oriented its leaves at a larger drooping angle of $51.4^{\circ}, 45^{\circ}$ and $43.2^{\circ}$ at $p F$ 2.0, 2.5 and 2.8 levels than other varieties. The orientation of leaves for cultivars followed a similar trend with cv. Kayinja drooping at $49.9^{\circ}, 42.2^{\circ}$ and $44.3^{\circ}$, cv Sukali ndiizi at $48.1^{\circ}, 46.3^{\circ}$ and $42.6^{\circ}$, cv. Mpologoma at $47.6^{0}, 42.4^{0}$ and $42.8^{0}$, cv. Yangambi Km5 at $46.5^{\circ}, 43.7^{0}$ and $44.1^{\circ}$ for $p F 2.0, p F 2.5$ and $p F 2.8$ levels respectively (Table 3 ). Leaf orientation trend across genotypes showed cv. Yangambi Km5 with most erect leaves and, therefore, had less potential for drought avoiding mechanism. The drooping potential meant the ability to expose a larger surface area that enhanced the high transpiration rate. However, a larger leaf drooping angle at $p F 2.0$ was potentially attributed to leaf 


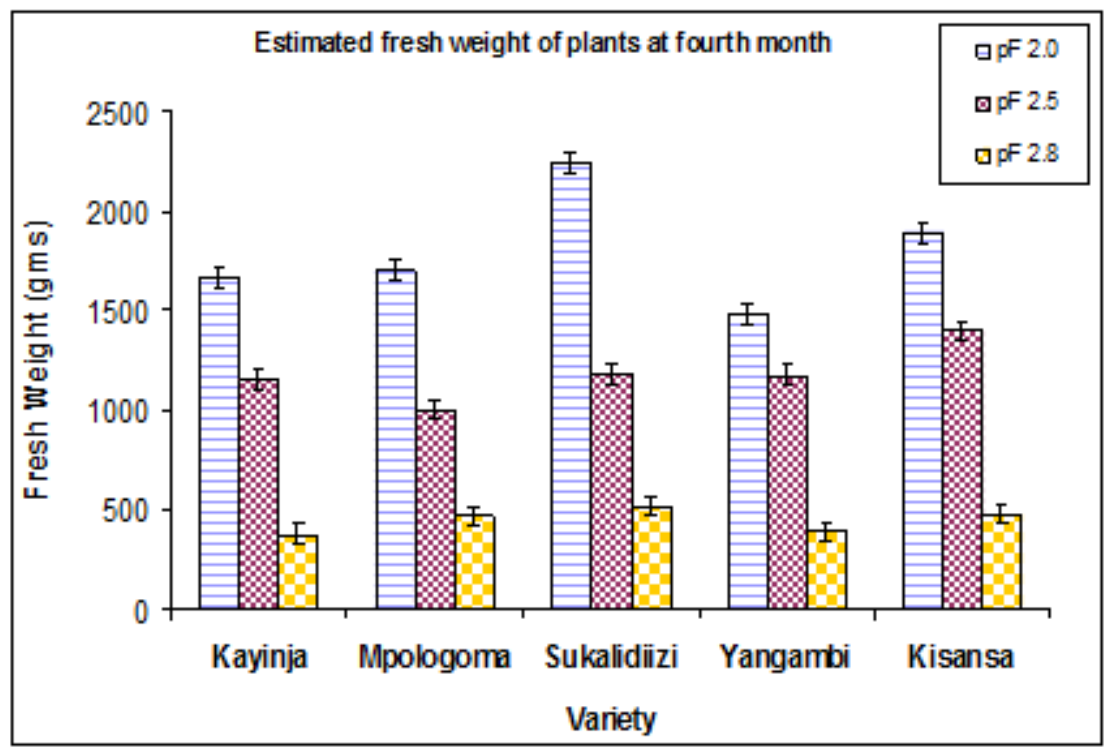

Figure 6. Fresh biomass accumulation (wgt) of selected banana cultivar.

weight and turgidity relative to the plant height than a mechanism for drought avoidance.

\section{Leaf folding architectural behaviour}

The decrease in soil water content $(p F$ 2.5 and 2.8 M.A.), from the field capacity, most likely caused a stress situation of plant dehydration and deterred leaf lamina expansion due to reduced leaf water potential (LWP). By avoiding a dehydration phenomenon of excessive loss of leaf water, plants folded their leaf lamina to reduce the leaf evaporative surface area. However, lowered transpiration through drought avoidance mechanism was considered to improve plant water use efficiency and maintaining relatively positive leaf water potential (Shmueli, 1953).

The phenomena of leaf midrib folding potentials were also similarly observed and reported by Kusaka (2005) on pearl millet. However, despite an avoidance mechanism to drought stress, the leaf orientation potential were also reported to lower photosynthetic activity through reduced the surface area for light interception and increased diffusion resistance to carbon dioxide $\left(\mathrm{Co}_{2}\right)$ (Kusaka, 2005). Among the cultivars potential for orienting leaves open, $\mathrm{cv}$. Yangambi Km5 $\left(126^{\circ}\right)$, cv. Kayinja $\left(125^{\circ}\right)$ and cv Kisansa $\left(124^{\circ}\right)$ were found to bear the leaves wide spread at $p F 2.0$ (Table 4), and the least orientations were observed among cv. Sukali ndiizi $\left(115.7^{\circ}\right)$, cv. Mpologoma $\left(116^{0}\right)$ (Fig. 8A), despite growing on free drainage media.

However, at $p F 2.5$, cv. Kisansa $\left(105^{\circ}\right)$ and Mpologoma $\left(109^{\circ}\right)$ folded their leaves than cv. Kayinja $\left(111.7^{\circ}\right)$ and cv. Sukali ndiizi $\left(111.7^{\circ}\right)$ (Fig. 8B). At $p F$ 2.8 , cv. Sukali ndiizi $\left(74.2^{\circ}\right)$, Mpologoma $\left(109^{\circ}\right)$ and cv. ksansa $\left(103.7^{\circ}\right)$ exhibited more folded leaves from $180^{\circ}$ surface orientation. The observation meant the cultivars had potential to avoid excessive dehydration and, therefore, some level of turgidity to facilitate dry matter translocation. The initial signs of folding mechanism (failure to orient leaves open 
Table 3. Leaf angle of selected banana cultivars across moisture deficit regimes

\begin{tabular}{|c|c|c|c|c|c|c|c|c|c|}
\hline Variety & $\begin{array}{l}\text { Moisture } \\
\text { regime } \\
\quad(p F)\end{array}$ & $\mathrm{Wk}_{9}$ & $\mathrm{Wk}_{10}$ & $\mathrm{Wk}_{11}$ & $\mathrm{Wk}_{12}$ & $\mathrm{Wk}_{13}$ & $\mathrm{Wk}_{14}$ & $\mathrm{Wk}_{15}$ & Mean \\
\hline \multirow{3}{*}{$\begin{array}{l}\text { Kayinja } \\
\text { (ABB) }\end{array}$} & 2.0 & 47.6 & 44.6 & 52.9 & 52.6 & 53.6 & 49.7 & 48.1 & 49.9 \\
\hline & 2.5 & 46.0 & 47.8 & 36.0 & 38.9 & 41.1 & 41.3 & 44.1 & 42.2 \\
\hline & 2.8 & 40.7 & 46.4 & 42.5 & 44.3 & 46.8 & 48.0 & 43.7 & 44.3 \\
\hline \multirow{3}{*}{$\begin{array}{l}\text { Mpologoma } \\
\text { (AAA) }\end{array}$} & 2.0 & 43.9 & 41.2 & 51.1 & 52.7 & 52.7 & 47.8 & 43.7 & 47.6 \\
\hline & 2.5 & 41.5 & 41.9 & 41.3 & 43.6 & 42.6 & 41.8 & 43.9 & 42.4 \\
\hline & 2.8 & 40.8 & 45.1 & 47.4 & 37.5 & 40.2 & 44.7 & 46.2 & 42.8 \\
\hline \multirow{3}{*}{$\begin{array}{l}\text { Sukali ndiizi } \\
\text { (AAB) }\end{array}$} & 2.0 & 38.9 & 36.3 & 56.4 & 57.1 & 58.3 & 41.7 & 48.2 & 48.1 \\
\hline & 2.5 & 42.1 & 44.4 & 47.3 & 51.9 & 55.3 & 40.9 & 42.1 & 46.3 \\
\hline & 2.8 & 47.4 & 34.2 & 39.4 & 42.4 & 47.2 & 42.5 & 46.7 & 42.6 \\
\hline \multirow{3}{*}{$\begin{array}{l}\text { Yangambi km5 } \\
\text { (AAA-LL) }\end{array}$} & 52.0 & 40.2 & 40.3 & 47.8 & 50.5 & 51.8 & 48.3 & 46.9 & 46.5 \\
\hline & 2.5 & 36.8 & 42.4 & 42.4 & 45.8 & 47.2 & 45.2 & 46.1 & 43.7 \\
\hline & 2.8 & 43.2 & 47.8 & 40.7 & 39.6 & 42.8 & 47.1 & 45.5 & 44.1 \\
\hline \multirow{6}{*}{$\begin{array}{l}\text { Kisansa } \\
\text { (AAA) }\end{array}$} & 2.0 & 48.1 & 48.6 & 55.6 & 55.8 & 57.6 & 50.1 & 43.7 & 51.4 \\
\hline & 2.5 & 41.5 & 40.9 & 44.7 & 50.3 & 49.1 & 44.7 & 43.9 & 45.0 \\
\hline & 2.8 & 40.9 & 39.4 & 45.4 & 40.7 & 46.9 & 47.6 & 43.3 & 43.2 \\
\hline & LSD (0.05)(M.A.) & 6.5 & 5.3 & 7.3 & 7.0 & 7.0 & 4.3 & 3.0 & \\
\hline & LSD (M.A.*V) & 10.9 & 12.3 & 25.6 & 11.2 & 9.3 & 5.5 & 14.5 & \\
\hline & $\mathrm{CV}(\%)$ & 23.1 & 18.1 & 21.1 & 21.5 & 19.8 & 12.6 & 9.1 & \\
\hline
\end{tabular}

MA = Moisture Availability, *means followed by the same letter within a column are not significantly different according to student-newman-Keuls $(\mathrm{S}-\mathrm{N}-\mathrm{K})$ test. Wk $=$ Week

to $180^{\circ}$ ) were observed upon moisture deficit increment at $p F 2.5$ and were more distinct at $p F 2.8$ in the order of cv. Sukali ndiizi at $74.2^{\circ}$, cv. Mpologoma at $98.9^{0}$ and cv. Kisansa at $103.7^{\circ}$ open, respectively. The polynomial regression trend showed a positive correlation of leaf angle and the potential to open wide at $p F 2.0$ (Fig. 7). The correlation was partly attributed to the leaf turgidity and size relative to proximal stem.

\section{Potential for leaf turgidity}

Most leaves across cultivar plants expressed full turgidity at $p F 2.0$, with $\mathrm{cv}$.
Kayinja containing more water (95.4\%), cv. Mpologoma, Sukali ndiizi and Kisansa (93.9, 93.3 and 93.2\%) RWC, respectively. At $p F 2.5$ M.A., cv. Mpologoma (cooking cultivar) retained relatively higher leaf turgidity $(93.6 \%)$ than cv. Sukali ndiizi (88.8\%), cv. Kayinja and Kisansa (89.9\% RWC), and Yangambi Km5 (85.5\%) (Table 5). Kayinja and yangambi $\mathrm{km} 5$ were more affected proportionally at 7.0 and $7.4 \%$ RWC reductions, respectively, than cv. Sukali ndiizi (4.8\%), cv. Kisansa (3.6\%) and cv. Mpologoma (0.3\%). The effects of turgidity reduction due to moisture 
Table 4. Leaf folding behavior of selected banana cultivars across different moisture regimes (Season2 (2008B)

\begin{tabular}{|c|c|c|c|c|c|c|c|c|c|}
\hline \multirow[t]{2}{*}{ Variety } & \multirow{2}{*}{$\begin{array}{l}\text { Moisture } \\
\text { regime } \\
(p F)\end{array}$} & \multicolumn{7}{|c|}{$\begin{array}{l}\text { Sampling intervals (Weekly) for Leaf surface opening } \\
\text { (inner midrib) }\end{array}$} & \multirow[t]{3}{*}{ Mean } \\
\hline & & Wk9 & Wk10 & Wk11 & Wk12 & Wk13 & Wk14 & Wk15 & \\
\hline & & \multicolumn{7}{|c|}{------- Degrees -----} & \\
\hline \multirow{3}{*}{$\begin{array}{l}\text { Kayinja } \\
\text { (ABB) }\end{array}$} & 2.0 & 137.0 & 139.0 & 116.7 & 124.7 & 130.0 & 117.0 & 110.7 & $125.1^{* *}$ \\
\hline & 2.5 & 131.7 & 134.0 & 95.7 & 99.7 & 109.7 & 105.7 & 105.3 & 111.7 \\
\hline & 2.8 & 127.7 & 130.0 & 106.7 & 112.3 & 115.3 & 85.3 & 85.3 & 109.0 \\
\hline \multirow{3}{*}{$\begin{array}{l}\text { Mpologoma } \\
\text { (AAA) }\end{array}$} & 2.0 & 103.7 & 104.7 & 115.0 & 120.0 & 130.7 & 115.7 & 122.0 & 116.0 \\
\hline & 2.5 & 118.0 & 119.3 & 101.0 & 107.3 & 117.7 & 94.7 & 106.3 & 109.2 \\
\hline & 2.8 & 106.0 & 107.7 & 93.7 & 98.3 & 103.7 & 88.0 & 95.0 & 98.9 \\
\hline \multirow{3}{*}{$\begin{array}{l}\text { Sukali ndiizi } \\
\text { (AAB) }\end{array}$} & 2.0 & 114.3 & 122.7 & 127.7 & 111.3 & 96.7 & 114.3 & 122.7 & 115.7 \\
\hline & 2.5 & 113.3 & 119.3 & 128.0 & 101.0 & 87.7 & 113.3 & 119.3 & 111.7 \\
\hline & 2.8 & 70.0 & 78.0 & 88.7 & 58.7 & 75.7 & 70.0 & 78.0 & 74.1 \\
\hline \multirow{3}{*}{$\begin{array}{l}\text { Yangambi Km5 } \\
\text { (AAA-LL) }\end{array}$} & 2.0 & 118.7 & 120.7 & 132.0 & 137.7 & 118.7 & 123.7 & 136.3 & 126.8 \\
\hline & 2.5 & 128.7 & 131.3 & 131.3 & 134.7 & 131.3 & 128.7 & 122.7 & 129.8 \\
\hline & 2.8 & 110.7 & 117.0 & 120.7 & 100.0 & 129.0 & 95.7 & 120.3 & 113.3 \\
\hline \multirow{3}{*}{$\begin{array}{l}\text { Kisansa } \\
\text { (AAA) }\end{array}$} & 2.0 & 113.3 & 114.3 & 140.0 & 148.7 & 161.3 & 99.0 & 91.7 & 124.1 \\
\hline & 2.5 & 109.7 & 110.7 & 99.3 & 106.3 & 101.0 & 102.0 & 108.0 & 105.3 \\
\hline & 2.8 & 121.0 & 120.7 & 94.7 & 99.3 & 105.0 & 90.0 & 95.0 & 103.5 \\
\hline \multicolumn{2}{|c|}{ LSD (0.05) (M.A.) } & 10.74 & 11.24 & 9.67 & 10.67 & 12.20 & 8.66 & 10.91 & \\
\hline \multicolumn{2}{|c|}{ LSD (0.05) (M.A.*V) } & 24.02 & 25.13 & 21.63 & 23.86 & 27.28 & 19.35 & 24.39 & \\
\hline \multicolumn{2}{|c|}{$\mathrm{CV}(\%)$} & 12.5 & 12.7 & 11.5 & 12.9 & 14.3 & 11.2 & 13.5 & \\
\hline
\end{tabular}

M.A. = Moisture Available, *means followed by the same letter within a column are not significantly different according to student-newman-Keuls (S-N-K) test.

deficit increment from $p F$ 2.0-2.5, were therefore, considered of less impact to cooking banana cultivars, but rather drought sensitivity to the desert and plantain type which justify the need to express the dehydration avoidance mechanisms for plant survival. Further increment in moisture deficit, in soil from $p F$ 2.5-2.8, indicated a higher water saturation deficit, hence, low turgidity in leaves.
The cooking banana types of cv. Mpologoma (84.5\% RWC) and Kisansa (82.1\% RWC) were more dehydrated hence the severe sensitivity to drought stress than cv. Sukali ndiizi $(85.9 \%)$ (Table 5, second season). The relative leaf turgidity enhanced cells to remain extended for transpiration, yet the lost water was far higher than the replaceable in soil hence the sensitivity and dificult to survive in adverse conditions. The leaves 


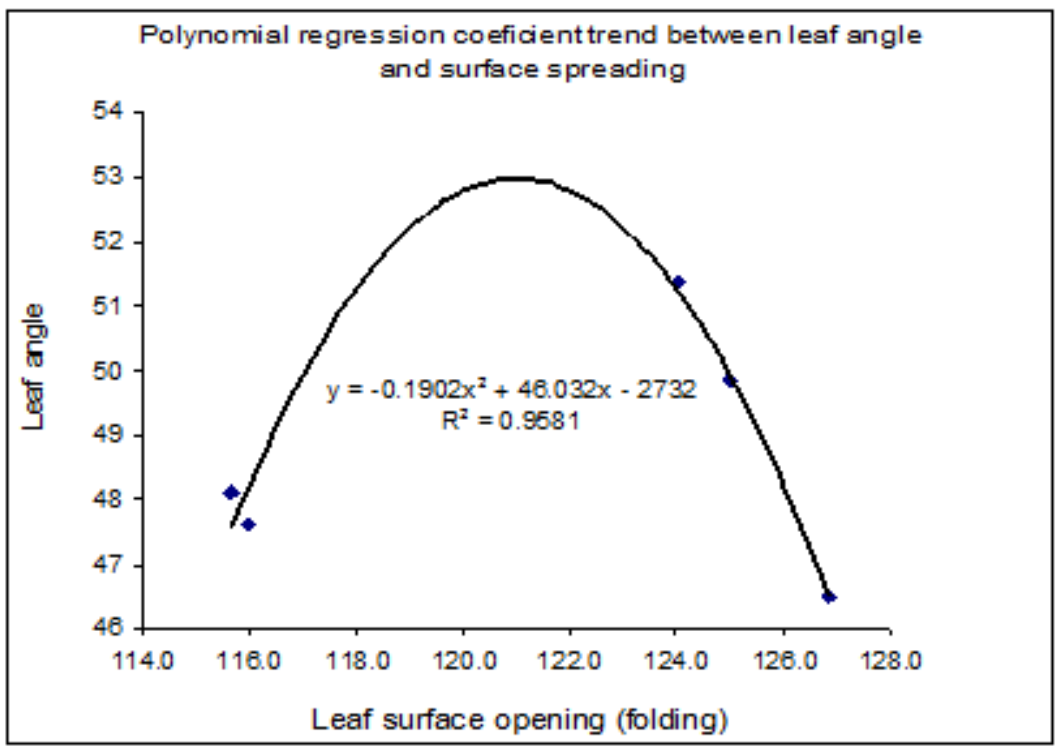

Figure 7. Correlation coefficient between leaf angle and folding for cultivars.

of other genotypes (Kayinja, Sukali ndiizi and Yangambi Km5) were relatively hydrated (83.3-90.2 RWC), a potential possibly attributed to possession of behavioural traits that enhanced mechanisms for drought avoidance. The proportions of leaf dehydration due to moisture deficit increment from $p F 2.5$ to 2.8, were higher for cv. Mpologoma (10.2\%) and cv. Kisansa (7.4) compared to cv. Kayinja and cv. Sukali ndiizi at 3.5 and $3.2 \%$, respectively.

\section{Selected metabolic processes of banana cultivar}

\section{Transpiration rates}

In the first season, the average transpired water was quantified at $1.631 \mathrm{~L} \mathrm{wk}^{-1}$, $1.209 \mathrm{~L} \mathrm{wk}^{-1}, 0.660 \mathrm{wk}^{-1}$ for $p F 2.0, p F 2.5$ and $p F 2.8$ respectively and across cultivars at $1.715 \mathrm{~L} \mathrm{wk}^{-1}$ (cv. Sukali ndiizi), $1.670 \mathrm{~L} \mathrm{wk}^{-1}$ (cv. Mpologoma), $1.595 \mathrm{~L} \mathrm{wk}^{-1}$ (cv. Kisansa), 1.581L wk ${ }^{-1}$ (cv. Kayinja) and $1.517 \mathrm{~L} \mathrm{wk}^{-1}$ (cv. Yangambi Km5) for the $p F$ 2.0. The results correlated significantly with the level of leaf surface expansion to enhance high transpiration rate (Table 6). However, at $p F 2.5$, the significant rates of transpiration trend were quantified at 1.245 $\mathrm{L}^{-1} 1$ (cv. Yangambi Km5), $1.238 \mathrm{~L}^{\mathrm{wk}}$ ${ }^{1}$ (cv. Sukali ndiizi), $1.222 \mathrm{~L} \mathrm{wk}^{-1}$ (cv. Kayinja), $1.186 \mathrm{~L} \mathrm{wk}^{-1}$ (cv. Mpologoma) and $1.156 \mathrm{~L} \mathrm{wk}^{-1}$ (cv. Kisansa) (Table 6). Similarly, the potential for spending a lot of water was correlated with the leaf surface expansion and opening. In the most stressful environment ( $p F 2.8$ ), plants showed distinct signs of dehydration, which necessitated the cultivar potential to save water from transpiration. Cultivars Kayinja $\left(0.553 \mathrm{~L} \mathrm{wk}^{-1}\right)$ and Sukali ndiizi $\left(0.620 \mathrm{~L} \mathrm{wk}^{-1}\right)$ exhibited water saving, contrary to cv. Kisansa $\left(0.770 \mathrm{~L} \mathrm{wk}^{-1}\right)$, cv. Mpologoma $\left(0.719 \mathrm{~L} \mathrm{wk}^{-1}\right)$ and cv. Yangambi Km5 $\left(0.637 \mathrm{~L} \mathrm{wk}^{-1}\right)$ that exhibited water spending, an attribute found valid with genotypic sensitivity to drought stress.

In the second season (9-20WAP), the transpiration rates for cultivars were 

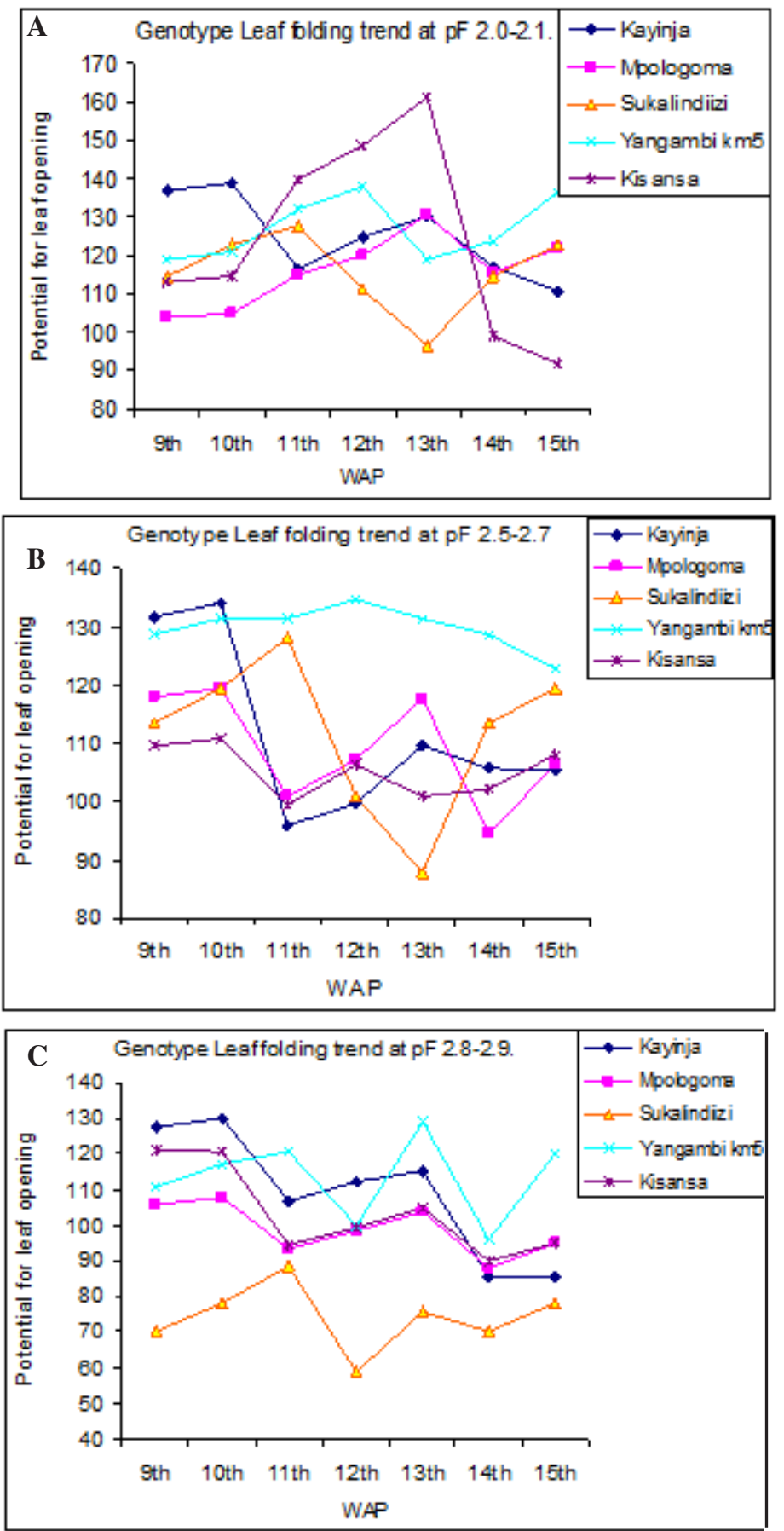

Figure 8. Trend of genotypic leaf folding for $p F 2.0 ; 2.5 ; 2.8$ (Fig 8A-C). 
Table 5. Relative leaf water content of selected banana cultivars across different moisture regimes

\begin{tabular}{|c|c|c|c|c|c|c|}
\hline Variety & $\begin{array}{l}\text { Moisture } \\
\text { regimes }\end{array}$ & $\mathrm{FW}$ & SW & DW & WC & WSD \\
\hline \multirow{5}{*}{$\begin{array}{l}\text { Kayinja (ABB) } \\
(\mathrm{ABB})\end{array}$} & $\mathrm{pF} 2.0$ & 0.46 & 0.47 & 0.09 & 95.35 & 4.65 \\
\hline & $\mathrm{pF} 2.5$ & 0.45 & 0.50 & 0.08 & 88.90 & 11.10 \\
\hline & $\mathrm{pF} 2.8$ & 0.43 & 0.49 & 0.08 & 85.90 & 14.15 \\
\hline & Lsd (M.A) & 0.07 & 0.06 & 0.02 & & \\
\hline & $\mathrm{CV}(\%)$ & 6.15 & 4.85 & 8.20 & & \\
\hline \multirow{5}{*}{$\begin{array}{l}\text { Mpologoma (AAA) } \\
\text { (AAA) }\end{array}$} & $\mathrm{pF} 2.0$ & 0.49 & 0.51 & 0.09 & 93.95 & 6.05 \\
\hline & $\mathrm{pF} 2.5$ & 0.47 & 0.50 & 0.09 & 93.65 & 6.35 \\
\hline & $\mathrm{pF} 2.8$ & 0.45 & 0.52 & 0.09 & 84.55 & 15.45 \\
\hline & Lsd (M.A) & 0.08 & 0.06 & 0.03 & & \\
\hline & $\mathrm{CV}(\%)$ & 6.35 & 4.25 & 14.15 & & \\
\hline \multirow{5}{*}{$\begin{array}{l}\text { Sukali ndiizi (AAB) } \\
\text { (AAB) }\end{array}$} & $\mathrm{pF} 2.0$ & 0.46 & 0.48 & 0.08 & 93.15 & 6.65 \\
\hline & $\mathrm{pF} 2.5$ & 0.43 & 0.48 & 0.08 & 88.80 & 11.20 \\
\hline & $\mathrm{pF} 2.8$ & 0.43 & 0.49 & 0.07 & 85.95 & 14.05 \\
\hline & Lsd (M.A) & 0.05 & 0.07 & 0.02 & & \\
\hline & $\mathrm{CV}(\%)$ & 4.35 & 6.00 & 10.90 & & \\
\hline \multirow[t]{5}{*}{ Yangambi (AAA-LL) } & $\mathrm{pF} 2.0$ & 0.45 & 0.49 & 0.08 & 91.95 & 8.00 \\
\hline & $\mathrm{pF} 2.5$ & 0.44 & 0.50 & 0.08 & 85.50 & 14.50 \\
\hline & $\mathrm{pF} 2.8$ & 0.43 & 0.49 & 0.07 & 85.35 & 14.65 \\
\hline & Lsd (M.A) & 0.05 & 0.05 & 0.02 & & \\
\hline & $\mathrm{CV}(\%)$ & 5.00 & 3.50 & 14.35 & & \\
\hline \multirow[t]{5}{*}{ Kisansa (AAA) } & $\mathrm{pF} 2.0$ & 0.46 & 0.48 & 0.08 & 93.25 & 6.75 \\
\hline & $\mathrm{pF} 2.5$ & 0.46 & 0.50 & 0.08 & 89.95 & 10.05 \\
\hline & $\mathrm{pF} 2.8$ & 0.43 & 0.51 & 0.08 & 82.05 & 17.95 \\
\hline & Lsd (M.A) & 0.09 & 0.04 & 0.02 & & \\
\hline & $\mathrm{CV}(\%)$ & 4.65 & 0.30 & 2.30 & & \\
\hline
\end{tabular}

RWC $=$ Relative Water Content, RWC $=(\mathrm{Fw}-\mathrm{Dw}) /(\mathrm{Sw}-\mathrm{Dw})$; WSD ie Water saturation deficit= $(\mathrm{Sw}-$ $\mathrm{Fw}) /(\mathrm{Sw}-\mathrm{Dw})$ ie 1-RWC; (Rampino, 2006) FW=Fresh Weight, SW=Saturated Weight, DW=Dry weight

quantified at $1.881 \mathrm{~L} \mathrm{wk}^{-1}, 1.222 \mathrm{~L} \mathrm{wk}^{-1}, \quad$ Yangambi $K m 5\left(1.869 \mathrm{~L} \mathrm{wk}^{-1}\right)$, cv. and $0.460 \mathrm{~L} \mathrm{wk}^{-1}$ for $p F$ 2.0, 2.5 and 2.8 Kayinja $\left(1.822 \mathrm{~L}^{-1}\right)$ and cv. respectively. However, at $p F$ 2.0, the Mpologoma (1.790 L wk-1) (Table 6). transpiration rates for cv. Sukali ndiizi Similarly, high rates of transpiration were and Kisansa were determined at $2.020 \mathrm{~L}$ attributed to leaf surface expansion and $\mathrm{wk}^{-1}$ and $1.903 \mathrm{~L} \mathrm{wk}^{-1}$, respectively per the potential to open wide. week, significantly different from cv. 


\begin{tabular}{|c|c|c|c|c|c|c|c|c|c|c|c|c|c|c|c|}
\hline Variety & Moisture & Transp & -- & --- & -- & - & Weekly s & ampling & interval & --- & --- & -- & --- & --- & Mean \\
\hline & & $(2008 \mathrm{~A})$ & $\mathrm{Wk}_{9}$ & $\mathrm{Wk}_{10}$ & $\mathrm{Wk}_{11}$ & $\mathrm{Wk}_{12}$ & $\mathrm{Wk}_{13}$ & $\mathrm{Wk}_{14}$ & $\mathrm{Wk}_{15}$ & $\mathrm{Wk}_{16}$ & $\mathrm{Wk}_{17}$ & $\mathrm{Wk}_{18}$ & $\mathrm{Wk}_{19}$ & $\mathrm{Wk}_{20}$ & \\
\hline & & & -- & --- & -- & -- & -- & Litres & - & -- & --- & -- & --- & --- & \\
\hline Kayinja & 2.0 & 1.581 & 0.94 & 1.248 & 1.676 & 2.068 & 2.011 & 2.224 & 1.971 & 2.208 & 1.726 & 1.789 & 1.970 & 2.014 & $1.822^{* *}$ \\
\hline$(\mathrm{ABB})$ & 2.5 & 1.222 & 0.558 & 0.841 & 1.195 & 1.404 & 1.277 & 1.470 & 1.322 & 1.396 & 1.220 & 1.245 & 1.356 & 1.433 & 1.226 \\
\hline & 2.8 & 0.553 & 0.264 & 0.345 & 0.359 & 0.340 & 0.393 & 0.274 & 0.225 & 0.173 & 0.173 & 0.215 & 0.234 & 0.256 & 0.271 \\
\hline Mpologoma & 2.0 & 1.670 & 1.002 & 1.190 & 1.521 & 1.941 & 1.996 & 2.224 & 2.090 & 2.219 & 1.640 & 1.686 & 1.938 & 2.030 & 1.790 \\
\hline (AAA) & 2.5 & 1.186 & 0.598 & 0.857 & 1.206 & 1.446 & 1.167 & 1.253 & 1.161 & 1.225 & 1.223 & 1.322 & 1.432 & 1.510 & 1.200 \\
\hline & 2.8 & 0.719 & 0.519 & 0.648 & 0.673 & 0.682 & 0.541 & 0.562 & 0.604 & 0.531 & 0.643 & 0.589 & 0.568 & 0.622 & 0.599 \\
\hline Sukali ndiizi & 2.0 & 1.715 & 0.920 & 1.285 & 1.716 & 2.095 & 2.444 & 2.792 & 2.577 & 2.720 & 1.883 & 1.913 & 1.995 & 1.897 & 2.020 \\
\hline$(\mathrm{AAB})$ & 2.5 & 1.238 & 0.625 & 0.868 & 1.139 & 1.267 & 1.195 & 1.179 & 1.059 & 1.122 & 1.220 & 1.276 & 1.378 & 1.439 & 1.147 \\
\hline & 2.8 & 0.620 & 0.492 & 0.439 & 0.523 & 0.504 & 0.431 & 0.366 & 0.365 & 0.321 & 0.388 & 0.394 & 0.335 & 0.387 & 0.412 \\
\hline Yangambi & 2.0 & 1.517 & 0.858 & 1.173 & 1.576 & 1.959 & 2.235 & 2.441 & 2.392 & 2.602 & 1.632 & 1.694 & 1.906 & 1.954 & 1.869 \\
\hline (AAA-LL) & 2.5 & 1.245 & 0.574 & 0.843 & 1.179 & 1.392 & 1.160 & 1.279 & 1.264 & 1.384 & 1.341 & 1.312 & 1.497 & 1.544 & 1.231 \\
\hline & 2.8 & 0.637 & 0.293 & 0.441 & 0.443 & 0.457 & 0.542 & 0.435 & 0.394 & 0.345 & 0.329 & 0.392 & 0.321 & 0.358 & 0.396 \\
\hline Kisansa & 2.0 & 1.595 & 1.025 & 1.270 & 1.719 & 2.223 & 2.071 & 2.240 & 2.134 & 2.268 & 1.797 & 1.857 & 2.098 & 2.137 & 1.903 \\
\hline (AAA) & 2.5 & 1.156 & 0.611 & 0.896 & 1.244 & 1.382 & 1.190 & 1.381 & 1.359 & 1.598 & 1.382 & 1.428 & 1.550 & 1.654 & 1.306 \\
\hline & 2.8 & 0.770 & 0.510 & 0.587 & 0.694 & 0.666 & 0.565 & 0.593 & 0.594 & 0.549 & 0.708 & 0.682 & 0.653 & 0.645 & 0.621 \\
\hline $\mathrm{LSD}(0.05)(\mathrm{Ml}$ & & & 0.068 & 0.091 & 0.088 & 0.086 & 0.132 & 0.156 & 0.133 & 0.149 & 0.111 & 0.114 & 0.112 & 0.104 & \\
\hline $\operatorname{LSD}(0.05)(\mathrm{MI}$ & $* V)$ & & & 0.152 & 0.202 & 0.197 & 0.192 & 0.294 & 0.348 & 0.298 & 0.333 & 0.249 & 0.256 & 0.251 & 0.233 \\
\hline $\mathrm{CV}(\%)$ & & & 14.0 & 14.1 & 10.5 & 8.7 & 13.7 & 15.0 & 13.7 & 14.4 & 12.9 & 12.9 & 11.7 & 10.5 & \\
\hline
\end{tabular}

*Means followed by the same letter within a column are not significantly different according to student-newman-Keuls (S-N-K) te 
At $p F 2.8$ (dry), actual expressions of traits for spending and saving water for plant growth was observed with cvs. Kisansa and Mpologoma significantly transpiring more water $\left(0.6 \mathrm{~L} \mathrm{wk}^{-1}\right)$; while cv. Sukali ndiizi $0.4 \mathrm{~L} \mathrm{wk}^{-1}$ and Yangambi $K m 5$; and $0.3 \mathrm{~L} \mathrm{wk}^{-1}$ for cv. Kayinja saved more water (transpired less). This drought stressful condition put cv Kisansa and Mpologoma to being water spenders, hence, their sensitivity and, therefore, could only get acclimatised to the environment than being adaptive, whereas cv. Sukali ndiizi, Yangambi and Kayinja exhibited relative traits of water saving.

The potential of cultivars to save water was considered a good trait for plant adaptability to survive in stressful conditions but not to be productive. However, the GxE results (Table 7, Fig. 9 A and B) showed cvs Sikali ndiizi and Yangambi $k m 5$ expressing stability at $p F$ 2.0; while the cooking cvs Mpologoma and Kisansa were stable at $p F 2.5$ proving the susceptibility to moisture stress. Cultivar Kayinja exhibited stability at both $p F 2.5$ and $p F 2.8$ confirming its adaptability in drought stressed environments (Table 7 Figs. 9 A and B). However, in characterisation of banana cultivars for drought stress, soil evaporation was controlled and allowed at least $95 \%$ transpiration through responsive plant tissue based on the weight loss method.

Multiple linear regression analysis, subject to stepwise ranking method, was used to identify plant growth parameters that contributed significantly to prediction of transpiration potential per genotype. A constant parameter enhanced the identification of responsive variables based on their grand mean; while t-statistic showed the level of transpiration compared to the degrees of freedom and also indicated the significant relationship between the regression parameters and transpiration. A correlation coefficient was determined to indicate the strength of predictive variables to transpiration per cultivar model as follows:

\section{Kayinja (ABB)}

(i) $\mathrm{Y}=[a(0.517)+\beta 1 * b 1(0.024)]$ $+[T K+T 0+M 0]$ for $(2008 \mathrm{~A})$

(ii) $\mathrm{Y}=[a(-3.68)+\beta 1 * b 1(0.020)+$ $\beta 2 * b 2(0.338)]+[T K+T 0+M 0]$ for (2008B)

Table 7. Cultivar performance (AMMI estimates)

\begin{tabular}{clclc}
\hline $\begin{array}{c}\text { Environment } \\
(p F)\end{array}$ & Genotype ranking & $\begin{array}{c}\text { Transpiration } \\
\text { rates (Litres/ } \\
48 \mathrm{hr})\end{array}$ & $\begin{array}{l}\text { Potential for } \\
\text { transpiration } \\
\text { Interaction }\end{array}$ & $\begin{array}{c}\text { Genotype x } \\
\text { environment }\end{array}$ \\
\hline 2.0-2.1(E1) & $\begin{array}{l}\text { Sukali ndiizi }(\mathrm{G} 3) \\
\text { Yangambi Km5 }(\mathrm{G} 4)\end{array}$ & 1.973 & $\begin{array}{l}\text { More water spender } \\
\text { Water spender }\end{array}$ & $\begin{array}{l}\text { Stable } \\
\text { Stable }\end{array}$ \\
& Kisansa $(\mathrm{G} 5)$ & 1.828 & Water spender & Stable \\
$2.5-2.7(\mathrm{E} 2)$ & Mpologoma $(\mathrm{G} 2)$ & 1.063 & Water spender & Stable \\
& Kayinja $(\mathrm{G} 1)$ & 1.048 & Water saver & Stable \\
& Kayinja $(\mathrm{G} 1)$ & 0.298 & Water saver & Stable \\
\hline
\end{tabular}




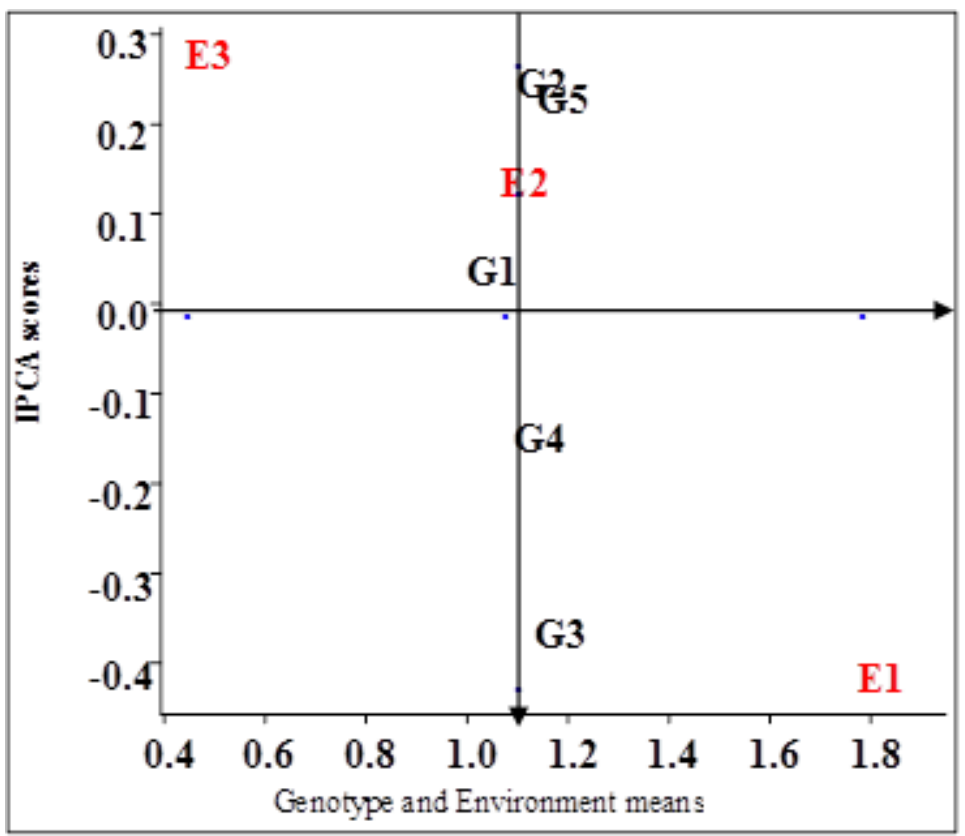

Figure 9A. Genotype by Environmental interaction for selected cultivars.

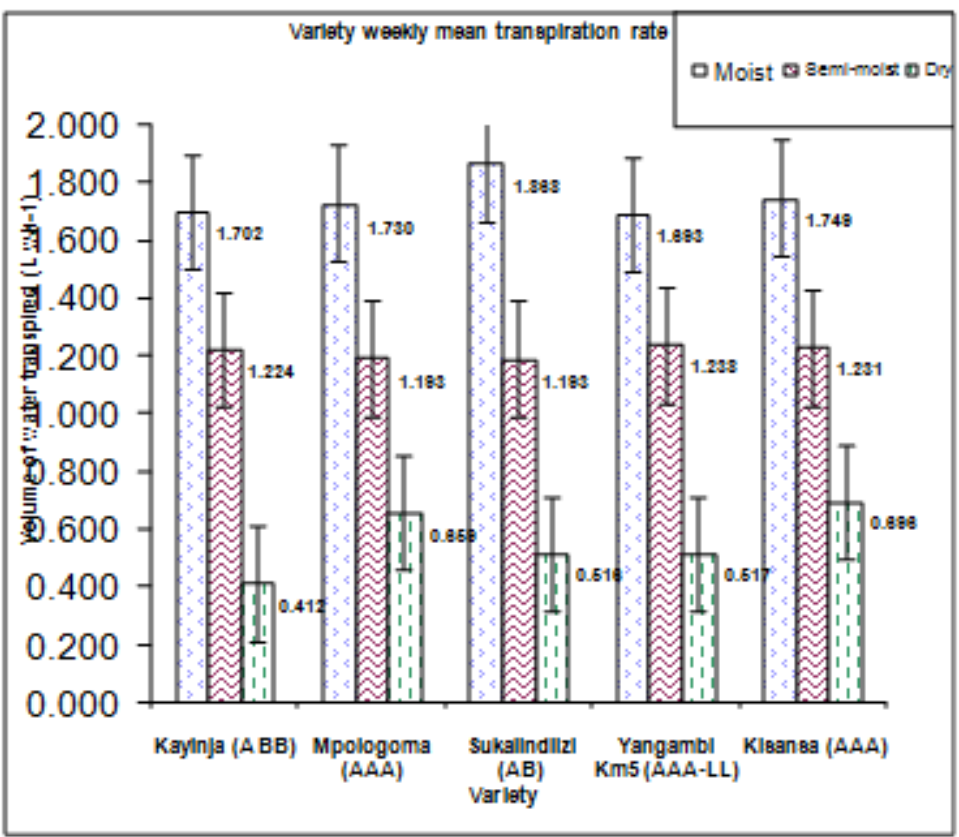

Figure 9B. Mean weekly transpiration rates of cultivars across different moisture levels. 
The model showed that transpiration increased by $0.024 \mathrm{~L}$ with each degree of leaf unfolding in $2008 \mathrm{~A}$ and by $0.338 \mathrm{~L}$ for each developed healthy leaf in 2008B. The observed strength between predicted parameters and transpiration showed a strongly inverse relationship (-81.3\%), indicating that transpiration decreases with leaf folding.

\section{Sukali ndiizi (AAB)}

(i) $\mathrm{Y}=[a(0.217)+\beta 1 * b 3(6.76)]+$ $[T K+T 0+M O]$ in $2008 \mathrm{~A}$

(ii) $\mathrm{Y}=[a(-2.408)+\beta 1 * b 1(0.012)+$ $\beta 2 * b 2(0.207)+\beta 3 * b 4(0.013)]$ $+[T K+T 0+M 0]$ in $2008 B$

The regression coefficient in the model indicated that transpiration of cv. Sukali ndiizi increased by $6.76 \mathrm{~L}$ of water for every fortnightly expansion in leaf area.

\section{Mpologoma (AAA)}

(i) $\mathbf{Y}=[a(0.418)+\beta 1 * b 5(0.001)+$ $(T K+T O+M O)]$ for $2008 \mathrm{~A}$

(ii) $\mathbf{Y}=[a(-0.890)+\beta 1 * b 1(0.016)+$ $\beta 2 * b 6(0.001)+(T K+T 0+M 0)]$ for the for 2008B

With the cooking type of cultivars, the determined regression coefficient for leaf area in the first model led to the prediction that transpiration increased by 0.001 grammes of water by $\mathrm{cm}^{2}$ expansion in leaf area. While in 2008A transpiration increased by 0.016 and $0.001 \mathrm{~g}$ per degree of leaf unfolding and per gramme increase in fresh leaf biomass. Other models for the other cultivars were determined as:

\section{Kisansa}

(i) $\mathrm{Y}=[\mathrm{a}(-0.160)+\beta 1 * \mathrm{~b} 3(9.00)+$ $\beta 2 * \mathrm{~b} 1(0.010)+(\mathrm{TK}+\mathrm{T} 0+\mathrm{M} 0)]$ for 2008A season

(ii) $\mathrm{Y}=[\mathrm{a}(-0.139)+\beta 1 * \mathrm{~b} 1(0.009)+$ $\beta 2 * \mathrm{~b} 6(0.001)+\mathrm{TK}+\mathrm{T} 0+\mathrm{M} 0$ ]for 2008B season

The regression coefficient in the first model predicted that transpiration significantly increased by $9.00 \mathrm{~g}$ with increment in leaf area $\left(\mathrm{cm}^{2}\right)$ per month and $0.009 \mathrm{~g}$ per degree of leaf unfolding. While in 2008B model, transpiration increased by 0.009 and $0.001 \mathrm{~g}$ with additional degree of leaf opening and gramme of fresh leaf biomass development.

\section{Yangambi km5}

(i) $\mathrm{Y}=[\mathrm{a}(-0.134)+\beta 1 * \mathrm{~b} 3(11.54)+\mathrm{TK}$ $+\mathrm{T} 0+\mathrm{M} 0]$ for 2008a season

(ii) $\mathrm{Y}=[\mathrm{a}(3.97)+\beta 1 * \mathrm{~b} 2(0.232)+\beta 2 *$ $\mathrm{b} 6(0.002)+\beta 3 * \mathrm{~b} 4(-0.04)+(\mathrm{TK}+$ $\mathrm{T} 0+\mathrm{M} 0)]$ for $2008 \mathrm{~b}$

Based on regression coefficients, the first model predicted that transpiration increased by $11.54 \mathrm{~g}$ per unit expansion in leaf area $\left(\mathrm{cm}^{2}\right)$ per month while in 2008B season, transpiration increased by 0.232 0.002 and $-0.04 \mathrm{~g}$ for healthy number of leaves, fresh leaf biomass and plant height, respectively.

Generally, the most observed predicting parameter with strong correlation coefficients in the models were leaf unfolding potential, healthy number of leaves and leaf area. The observation is valid based on leaf architectural behaviour 
in for of development, expansion of surface area and remaining un folded.

\section{Chlorophyll $(a+b)$ response}

Response of chlorophyll was determined based on absorption of the specific wavelength of light recorded by the SPAD meter. Significant differences of chlorophyll content in leaves were observed among cooking type of cultivars (Kisansa and Mpologoma) across seasons. Chlorophyll concentrations in leaves were significantly higher in plants subjected to field capacity $(p F 2.0)$ and decreased upon increased moisture deficit levels ( $p F 2.5$ and 2.8), particularly among the cooking type of cultivars (Mpologoma and Kisansa). Similarly, Lavah (1995) observed critical concentrations of nutrients within the banana germplasm with A-genome genotypes requiring high levels of nutrients. The lower chlorophyll concentrations were partly attributed to weak distribution of nutrients to the development of young leaves hence disappearing of the green colour and appearance of photochemical damage on leaves.

Generally, across moisture deficit levels, cv Mpologoma exhibited the highest concentrations of chlorophyll in leaves (2008B season). Cultivar Yangambi Km5 (AAA-lowland) exhibited no differences in rates of chlorophyll across moisture deficit levels over seasons, suggesting that the reduction in available soil water did not affect chlorophyll progress in leaves. But cv. Sukali ndiizi (AAB) exhibited lower rates of nitrogen content $\left(49,46.2\right.$ and $45.3 \mathrm{mg} \mathrm{g}^{-1}$ for $p F$ $2.0,2.5$ and 2.8, respectively) in leaves in the 2008A season and increased significantly at rates of $54 \mathrm{mg} \mathrm{g}^{-1}, 57.4$ and 58.7 for $p F 2.0$, and 2.8 , respectively in 2008B season.
The rates of nitrogen progress were not affected by increased moisture deficit over both seasons. In the most stressful condition, nitrogen content rates remained low, suggesting weak potential for nutrient remobilisation and development of young leaves for cv. Sukali ndiizi. However, cv. Kayinja exhibited the lowest rates of nitrogen content (39.5 - $42.1 \mathrm{mg} \mathrm{g}^{-1} ; 48.8$ - $51.5 \mathrm{mg} \mathrm{g}^{-1}$ ) in leaves across seasons. The non significance in rates of chlorophyll progress, suggested little effect of increased moisture deficit hence cultivar ability to survive during drought stress. Strong nutrient redistribution to the development of young leaves may have been observed over time in 2008B season as judged by senescence of older leaves and chlorophyll content in young leaves.

\section{References}

Bananuka, J.A, Rubaihayo, P.R., Tenywa, M.M. 1999. Reactions of Musa genotypes to drought stress. African Crop Science Journal 7:333-339.

Kumar, C.P. and Mittal, S. 2010. Soil moisture retention characteristics and hydraulic conductivity for different areas in India in selected states

Ostonen, I., Puttsepp, U., Biel, C., Alberton, O., Bakker, M.R., Lohmus, K., Madji, H., Metcalfe ,D., Olsthoorn, A.F.M., Pronk, A., Vanguelova, E., Weith, M. and Brunner, I. 2007. Specific root length as an indicator of environmental Change. Plant Biosystems 141(3):426-442.

Paknejad, F., Nasri, M., Reza, H., Moghadam, T., Zahedi, H. and Alahmadi, M.J. 2007. Effects of drought stress on chlorophyll fluorescence parameters, chlorophyll content and grain yield of wheat cultivars. 
Sebuwufu, G., Rubaihayo, P.R. and Blomme, G. 2004. Variability in the root system of East African banana genotypes in Conservation through utilization of banana and plantain in the Great Lakes Region of East Africa.
African Crops Science Journal (Special issue) 12(1):85-93.

Van Asten, P.J.A., Taulya, G., Okech, S.H., Gold, C.S. and Mugaga, T.K.W. 2007. Drought is a major yield loss factor for East African Higland banana (cv. Enyeru) 